\title{
Time series of tritium, stable isotopes and chloride reveal short-term variations in groundwater contribution to a stream
}

\author{
C. Duvert ${ }^{1}$, M. K. Stewart ${ }^{2}$, D. I. Cendón ${ }^{3,4}$, and M. Raiber ${ }^{5}$ \\ ${ }^{1}$ Queensland University of Technology, Brisbane, QLD 4001, Australia \\ ${ }^{2}$ Aquifer Dynamics Ltd \& GNS Science, P.O. Box 30368, Lower Hutt, 5040, New Zealand \\ ${ }^{3}$ Australian Nuclear Science and Technology Organisation, Kirrawee DC, NSW 2232, Australia \\ ${ }^{4}$ School of Biological, Earth \& Environmental Sciences, University of New South Wales, Sydney, NSW 2052, Australia \\ ${ }^{5}$ CSIRO Land \& Water, Dutton Park, Brisbane, QLD 4102, Australia \\ Correspondence to: C. Duvert (clement.duvert@gmail.com)
}

Received: 23 July 2015 - Published in Hydrol. Earth Syst. Sci. Discuss.: 18 August 2015

Revised: 9 November 2015 - Accepted: 11 December 2015 - Published: 18 January 2016

\begin{abstract}
A major limitation to the assessment of catchment transit time (TT) stems from the use of stable isotopes or chloride as hydrological tracers, because these tracers are blind to older contributions. Yet, accurately capturing the TT of the old water fraction is essential, as is the assessment of its temporal variations under non-stationary catchment dynamics. In this study we used lumped convolution models to examine time series of tritium, stable isotopes and chloride in rainfall, streamwater and groundwater of a catchment located in subtropical Australia. Our objectives were to determine the different contributions to streamflow and their variations over time, and to understand the relationship between catchment TT and groundwater residence time. Stable isotopes and chloride provided consistent estimates of TT in the upstream part of the catchment. A young component to streamflow was identified that was partitioned into quickflow (mean TT $\approx 2$ weeks) and discharge from the fractured igneous rocks forming the headwaters (mean $\mathrm{TT} \approx 0.3$ years). The use of tritium was beneficial for determining an older contribution to streamflow in the downstream area. The best fits between measured and modelled tritium activities were obtained for a mean TT of 16-25 years for this older groundwater component. This was significantly lower than the residence time calculated for groundwater in the alluvial aquifer feeding the stream downstream $(\approx 76-102$ years $)$, emphasising the fact that water exiting the catchment and water stored in it had distinctive age distributions. When simulations were run separately on each tritium streamwater sample, the TT of old water fraction varied substantially over time, with values
\end{abstract}

averaging $17 \pm 6$ years at low flow and $38 \pm 15$ years after major recharge events. This counterintuitive result was interpreted as the flushing out of deeper, older waters shortly after recharge by the resulting pressure wave propagation. Overall, this study shows the usefulness of collecting tritium data in streamwater to document short-term variations in the older component of the TT distribution. Our results also shed light on the complex relationships between stored water and water in transit, which are highly non-linear and remain poorly understood.

\section{Introduction}

Catchment transit time (TT) can be defined as the time water spends travelling through a catchment, from infiltrating precipitation until its exit through the stream network (McDonnell et al., 2010). Because this parameter integrates information on storage, flow pathways and source of water in a single value, it has been increasingly used as a generic indicator of catchment dynamics (McGuire and McDonnell, 2006). Accurate quantification of TT is of prime importance for water resource management issues, in particular for the assessment of catchment sensitivity to anthropogenic inputs such as fertilizers or herbicides (e.g. van der Velde et al., 2010; Benettin et al., 2013), and for the provision of additional constraints on catchment-scale hydrological models (e.g. Gusyev et al., 2013). TT is estimated by relating the signature of a tracer measured in a sample taken at the outlet of a catchment to the 
history of the tracer input in rainfall-derived recharge water. Interpretation of TT data is often problematic because a single sample typically contains water parcels with different recharge histories, different flowpaths to the stream and thus different ages. This is exacerbated when the catchment is underlain by heterogeneous aquifers, as dispersion and mixing of different water sources can lead to very broad spectra of ages (Weissmann et al., 2002). Rather than a single scalar value, samples are therefore characterised by a TT distribution (i.e. probability density function of the TTs contained in the sample). The residence time (RT) distribution is another useful indicator that refers to the distribution of ages of water resident within the system, rather than exiting it. RT distributions are generally used to characterise subsurface water or deeper groundwater that is stored in the catchment.

In the last 2 decades, a great deal of effort has been directed to the determination of catchment TTs in a variety of streams and rivers worldwide (e.g. Maloszewski et al., 1992; Burns et al., 1998; Soulsby et al., 2000; Rodgers et al., 2005; Dunn et al., 2010). Attempts have been made to correlate the TTs to catchment characteristics such as topography (McGuire et al., 2005; Mueller et al., 2013; Seeger and Weiler, 2014), geology (Katsuyama et al., 2010) or soil type (Tetzlaff et al., 2009, 2011; Timbe et al., 2014). Assessment of the relationship between groundwater RT and catchment TT has also been undertaken occasionally (Matsutani et al., 1993; Herrmann et al., 1999; Reddy et al., 2006). Because catchment storage is highly non-stationary, catchment TTs are known to vary over time (McDonnell et al., 2010), yet the importance of temporal dynamics in TT distributions has been overlooked until recently. One of the reasons is that this non-stationarity is not accounted for in the models commonly used in catchment TT research. In the last 5 years, an ever-growing number of studies has transferred its focus to assessing dynamic TT distributions (Hrachowitz et al., 2010, 2013; Roa-García and Weiler, 2010; Rinaldo et al., 2011; Cvetkovic et al., 2012; Heidbüchel et al., 2012, 2013; McMillan et al., 2012; Tetzlaff et al., 2014; Birkel et al., 2015; van der Velde et al., 2015; Benettin et al., 2015; Harman, 2015; Klaus et al., 2015a; Kirchner, 2015). Most of these studies agreed on the importance of considering storage dynamics, because the RT distribution of storage water and the TT distribution of water transiting at the outlet of the catchment are likely to be very different. Concurrently to these recent advances in catchment hydrology, groundwater scientists have also developed new theoretical bases for the incorporation of transient conditions in RT distribution functions (Massoudieh, 2013; Leray et al., 2014). Nonetheless, the determination of time-variant TT and RT distributions requires data-intensive computing, which still largely limits their use in applied studies (Seeger and Weiler, 2014).

A simple, yet still widely used alternative to more sophisticated models is the lumped-parameter modelling approach, which has been developed since the 1960s to interpret age tracer data (Vogel, 1967; Eriksson, 1971; Maloszewski and
Zuber, 1982). Lumped models require minimal input information, and are based on the assumptions that the shape of the TT or RT distribution function is a priori known and that the system is at steady state. The relationship between input and output signatures is determined analytically using a convolution integral, i.e. the amount of overlap of the TT or RT distribution function as it is shifted over the input function. Some of the lumped models consider only the mechanical advection of water as driver of tracer transport (e.g. exponential model), while others also account for the effects of dispersion-diffusion processes (e.g. dispersion model). Nonparametric forms of RT distribution functions have recently been developed (Engdahl et al., 2013; Massoudieh et al., 2014b; McCallum et al., 2014), but again, these more recent approaches require a higher amount of input data, which makes the standard lumped-parameter approach a method of choice for the time being.

Commonly used to determine TT distributions using such models are the stable isotopes of water $\left(\delta^{2} \mathrm{H}\right.$ and $\left.\delta^{18} \mathrm{O}\right)$. Because they are constituents of the water molecule itself, ${ }^{2} \mathrm{H}$ and ${ }^{18} \mathrm{O}$ follow almost the same response function as the traced material, hence are generally referred to as "ideal" tracers. Another tracer that behaves relatively conservatively and has been often used in the literature is chloride. An important issue with using ${ }^{2} \mathrm{H},{ }^{18} \mathrm{O}$ and/or chloride as TT indicators is that detailed catchment-specific input functions are needed (ideally at a weekly sampling frequency for several years), and such data are rare globally. More importantly, Stewart et al. $(2010,2012)$ criticised the use of these tracers to assess catchment TTs, arguing that TT distributions are likely to be truncated when only ${ }^{2} \mathrm{H}$ and/or ${ }^{18} \mathrm{O}$ are used. In an earlier study, Stewart et al. (2007) reported differences of up to an order of magnitude between the TTs determined using stable isotopes as compared to those determined using tritium $\left({ }^{3} \mathrm{H}\right)$. Later works by Seeger and Weiler (2014) and Kirchner (2015) reinforced the point that "stable isotopes are effectively blind to the long tails of TT distributions" (Kirchner, 2015). The effects of older groundwater contributions to streamflow have largely been ignored until recently (Smerdon et al., 2012; Frisbee et al., 2013), and according to Stewart et al. (2012), new research efforts need to be focused on relating deeper groundwater flow processes to catchment response. Accounting for potential delayed contributions from deeper groundwater systems therefore requires the addition of a tracer, such as ${ }^{3} \mathrm{H}$, that is capable of determining longer TTs.

${ }^{3} \mathrm{H}$ is a radioactive isotope of hydrogen with a half-life of 12.32 years. Like ${ }^{2} \mathrm{H}$ and ${ }^{18} \mathrm{O}$ it is part of the water molecule and can therefore be considered an "ideal" tracer. Fractionation effects are small and can be ignored relative to measurement uncertainties and to its radioactive decay (Michel, 2005). The bomb pulse ${ }^{3} \mathrm{H}$ peak that occurred in the 1960s was several orders of magnitude lower in the Southern Hemisphere than in the Northern Hemisphere (Freeze and Cherry, 1979; Clark and Fritz, 1997), and the ${ }^{3} \mathrm{H}$ con- 
centrations of remnant bomb pulse water have now decayed well below that of modern rainfall (Morgenstern and Daughney, 2012). These characteristics allow the detection of relatively older groundwater (up to 200 years) and, importantly, the calculation of unique TT distributions from a single ${ }^{3} \mathrm{H}$ value, provided the measurement is accurate enough (Morgenstern et al., 2010; Stewart et al., 2010). Other age tracers such as chlorofluorocarbons and sulfur hexafluoride have shown potential for estimating groundwater RT (e.g. Cook and Solomon, 1997; Lamontagne et al., 2015); however, these tracers are less suitable for streamwater because of gas exchange with the atmosphere (Plummer et al., 2001).

Long-term evolution of ${ }^{3} \mathrm{H}$ activity within catchments has been reported in a number of studies, both for the determination of RT in groundwater systems (e.g. Zuber et al., 2005; Stewart and Thomas, 2008; Einsiedl et al., 2009; Manning et al., 2012; Blavoux et al., 2013) and for the assessment of TT in surface water studies (Matsutani et al., 1993; Stewart et al., 2007; Morgenstern et al., 2010; Stolp et al., 2010; Stewart, 2012; Gusyev et al., 2013; Kralik et al., 2014). Most of these studies had to assume stationarity of the observed system by deriving a unique estimate of TT or RT from ${ }^{3} \mathrm{H}$ time-series data, in order to circumvent the bomb pulse issue. Benefiting from the much lower ${ }^{3} \mathrm{H}$ atmospheric levels in the Southern Hemisphere, Morgenstern et al. (2010) were the first to use repeated streamwater ${ }^{3} \mathrm{H}$ data to assess the temporal variations in TT distributions. Using simple lumped parameter models calibrated to each ${ }^{3} \mathrm{H}$ sample, they established that catchment TT was highly variable and a function of discharge rate. Following the same approach, Cartwright and Morgenstern (2015) explored the seasonal variability of ${ }^{3} \mathrm{H}$ activities in streamwater and their spatial variations from headwater tributaries to a lowland stream. They showed that different flowpaths were likely to have been activated under varying flow conditions, resulting in a wide range of TTs. To the extent of our knowledge, shorter-term (i.e. less than monthly) variations in streamwater ${ }^{3} \mathrm{H}$ and their potential to document rapid fluctuations in the older groundwater component in streamflow have not been considered in the literature.

This study investigates the different contributions to streamflow in a subtropical headwater catchment subjected to highly seasonal rainfall, as well as their variations over time. The overarching goal is to advance our fundamental understanding of the temporal dynamics in groundwater contributions to streams, through the collection of time series of seasonal tracers, i.e. tracers subject to pronounced seasonal cycles $\left({ }^{2} \mathrm{H},{ }^{18} \mathrm{O}\right.$ and chloride), and ${ }^{3} \mathrm{H}$. We postulate that ${ }^{3} \mathrm{H}$ time-series data may provide insight into the non-linear processes of deeper groundwater contribution to rivers. Specifically, the questions to be addressed are the following.

i. Can simple lumped models provide reliable estimates of catchment TTs in catchments characterised by intermittent recharge and high evapotranspiration rates?

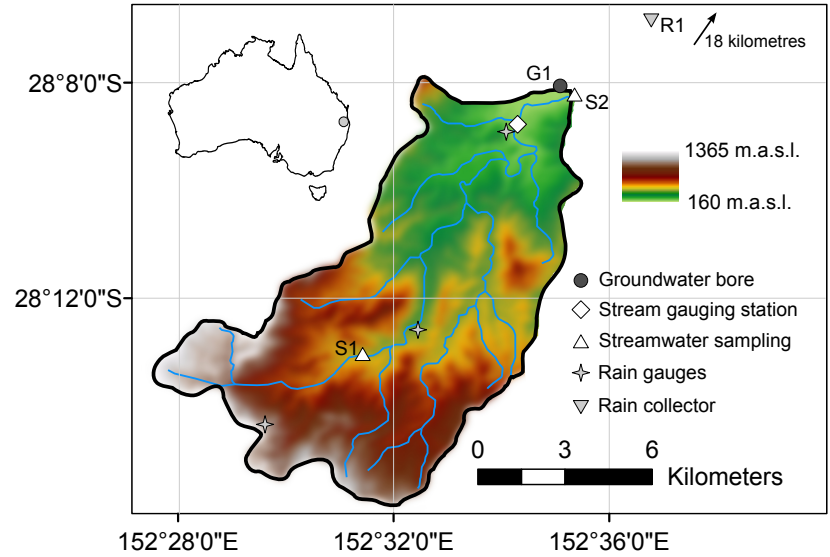

Figure 1. Upper Teviot Brook catchment and location of sampling sites. The stream gauging station corresponds to Teviot Brook at Croftby (145011A; operated by the Queensland Department of Natural Resources and Mines). The rainfall gauges correspond to Wilsons Peak Alert (040876), Carneys Creek The Ranch (040490) and Croftby Alert (040947), all run by the Bureau of Meteorology.

ii. Can short-term variations in older (5-100 years) groundwater contributions be captured by ${ }^{3} \mathrm{H}$ timeseries data?

iii. How dissimilar are the RT of aquifers adjacent to streams (i.e. storage water) and the transit time of streamwater (i.e. exiting water)?

\section{Study area}

\subsection{Physical setting}

The upper Teviot Brook catchment is located south-west of Brisbane (south-eastern Queensland, Australia), with its headwaters in the Great Dividing Range (Fig. 1). It covers an area of $95 \mathrm{~km}^{2}$, and elevations range between 160 and 1375 ma.s.1.. Climate in the region is humid subtropical with extremely variable rainfall: mean annual precipitation for the catchment is $970 \mathrm{~mm}$ (1994-2014 period), of which $76 \%$ falls from November to April. While Teviot Brook is a perennial stream, the distribution of discharge is uneven throughout the year: the mean annual discharge is $120 \mathrm{~mm}$ (19942014 period), with highest and lowest streamflow occurring in February (average $40 \mathrm{~mm}$ ) and September (average $2 \mathrm{~mm}$ ), respectively. The headwaters support undisturbed subtropical rainforest, while the valley supports open woodland and grassland.

The first sampling location (S1) is situated in a steep, narrow valley where the stream erodes into the fractured, silicarich igneous rocks forming the headwaters. At this upstream location, boulders, gravel and sand constitute the streambed substrate as well as near-channel deposits. The second sampling location (S2) lies further downstream where the val- 
ley is flatter and forms a wide alluvial plain. At this downstream location the stream is incised into the alluvial deposits, which at G1 are composed of fine-grained material, i.e. mostly gravel and silty clay. Underlying the alluvial deposits is a sedimentary bedrock formation (Walloon Coal Measures) consisting of irregular beds of sandstone, siltstone, shale and coal, some of which contain significant volumes of groundwater. Duvert et al. $(2015 b$, a) reported high $\mathrm{Fe}$ concentrations and low ${ }^{3} \mathrm{H}$ activities for some groundwaters of the sedimentary bedrock.

Hydraulic gradient analysis indicates that the alluvium mostly drains into the stream; hydrochemical and isotopic data also revealed a close connection between the alluvium and surface water in the Teviot Brook catchment (Duvert et al., 2015b). Borehole G1 is $13.9 \mathrm{~m}$ deep and it is screened from $12.3 \mathrm{~m}$ to its bottom, i.e. entirely within the alluvial stratum. The horizontal distance between $\mathrm{G} 1$ and $\mathrm{S} 2$ is $60 \mathrm{~m}$.

\subsection{Catchment hydrology}

The monitoring period spans over 2 years, from mid-2012 to late 2014. Daily streamflow data were obtained from a gauging station operated by the Queensland Department of Natural Resources and Mines (Croftby station; 145011A) and located $2 \mathrm{~km}$ upstream of S2 (Fig. 1). Daily precipitation data were available at three rain gauges spread across the catchment and operated by the Australian Bureau of Meteorology. Average precipitation was calculated from the three records using the Thiessen method. Annual precipitation amounted to $1010 \mathrm{~mm}$ in 2012, $1190 \mathrm{~mm}$ in 2013 and $960 \mathrm{~mm}$ in 2014 . The rainfall depths recorded in the headwaters were 100 to $250 \mathrm{~mm}$ higher than those in the floodplain. The maximum daily rainfall amount was $275 \mathrm{~mm}$ and occurred in late January 2013, with a weekly value of $470 \mathrm{~mm}$ for this same event (Fig. 2a). This intense episode of rainfall generated a daily peak flow of $137 \mathrm{~m}^{3} \mathrm{~s}^{-1}$ upstream of S2 (Fig. 3b), which corresponds to a 22-year return period event at that station - calculated by fitting long-term data to a Galton distribution. Earlier work has shown that this major event contributed significantly to recharge of the alluvial and bedrock aquifers in the headwaters (Duvert et al., 2015a, b). Another high flow event occurred in late March 2014, with a daily peak flow of $39 \mathrm{~m}^{3} \mathrm{~s}^{-1}$. Generally, examination of the hydrograph reveals that extended recession periods followed peak flows. Low flow conditions $\left(Q<0.01 \mathrm{~m}^{3} \mathrm{~s}^{-1}\right)$ occurred towards the end of the dry season, i.e. approximately from November through to January (Fig. 2b). The stream did not dry up during the study period although very low flow $(Q<$ $0.001 \mathrm{~m}^{3} \mathrm{~s}^{-1}$ ) occurred for 30 consecutive days in FebruaryMarch 2014.

\section{Methods}

\subsection{Sample collection and analysis}

Bulk samples of precipitation were collected at R1 (Fig. 1) at fortnightly to monthly intervals using a Palmex RS1 rainfall collector, which allows virtually evaporation-free sampling (Gröning et al., 2012). Streamwater and groundwater samples were collected at S1 and S2 (stream sampling locations) and G1 (alluvial aquifer) following the same sampling design as the rainfall samples. Samples at G1 were taken after measuring the water table level and purging a minimum of three casing volumes with a stainless steel submersible pump (Hurricane XL, Proactive). All samples were filtered through $0.45 \mu \mathrm{m}$ membrane filters, and care was taken to seal the bottles and vials tightly to avoid evaporation.

Stable isotopes and chemical elements were measured for all samples at R1, S1, S2, and G1. ${ }^{3} \mathrm{H}$ activity was determined at S2 for most samples, and at G1 for one sample. Chloride concentrations were measured using ion chromatography (ICS-2100, Dionex), while iron and silicon were measured using inductively coupled plasma optical emission spectrometry (Optima 8300, Perkin Elmer). Total alkalinity was measured by titrating water samples with hydrochloric acid to a $\mathrm{pH}$ endpoint of 4.5. Major ions were assessed for accuracy by evaluating the charge balance error, which was $<10 \%$ for all samples and $<5 \%$ for $93 \%$ of the samples. Samples were also analysed for ${ }^{18} \mathrm{O}$ and ${ }^{2} \mathrm{H}$, using a Los Gatos Research water isotope analyser (TIWA-45EP). All isotopic compositions in this study are expressed relative to the VSMOW standard ( $\delta$ notation). Between-sample memory effects were minimised by pre-running all samples and subsequently re-measuring them with decreasing isotopic ratios, as recommended in Penna et al. (2012). Replicate analyses indicate that analytical error was $\pm 1.1 \%$ for $\delta^{2} \mathrm{H}$ and $\pm 0.3 \%$ ofor $\delta^{18} \mathrm{O}$. All these analyses were conducted at the Queensland University of Technology (QUT) in Brisbane. In addition, ${ }^{3} \mathrm{H}$ was analysed at the Australian Nuclear Science and Technology Organisation (ANSTO) in Sydney. Samples were distilled and electrolytically enriched 68 -fold prior to counting with a liquid scintillation counter for several weeks. The limit of quantification was 0.05 tritium units (TU) for all samples, and uncertainty was $\pm 0.06 \mathrm{TU}$. A sample collected in August 2013 was excluded from the data set since it was analysed twice and yielded inconsistent results.

\subsection{Tracer-based calculation of transit and residence times}

\subsubsection{Using stable isotopes and chloride}

Mean TTs were determined through adjustment of a TT distribution function to observations of fortnightly input and output signatures (here the term "signature" is meant to encompass either an ionic concentration or an isotopic com- 

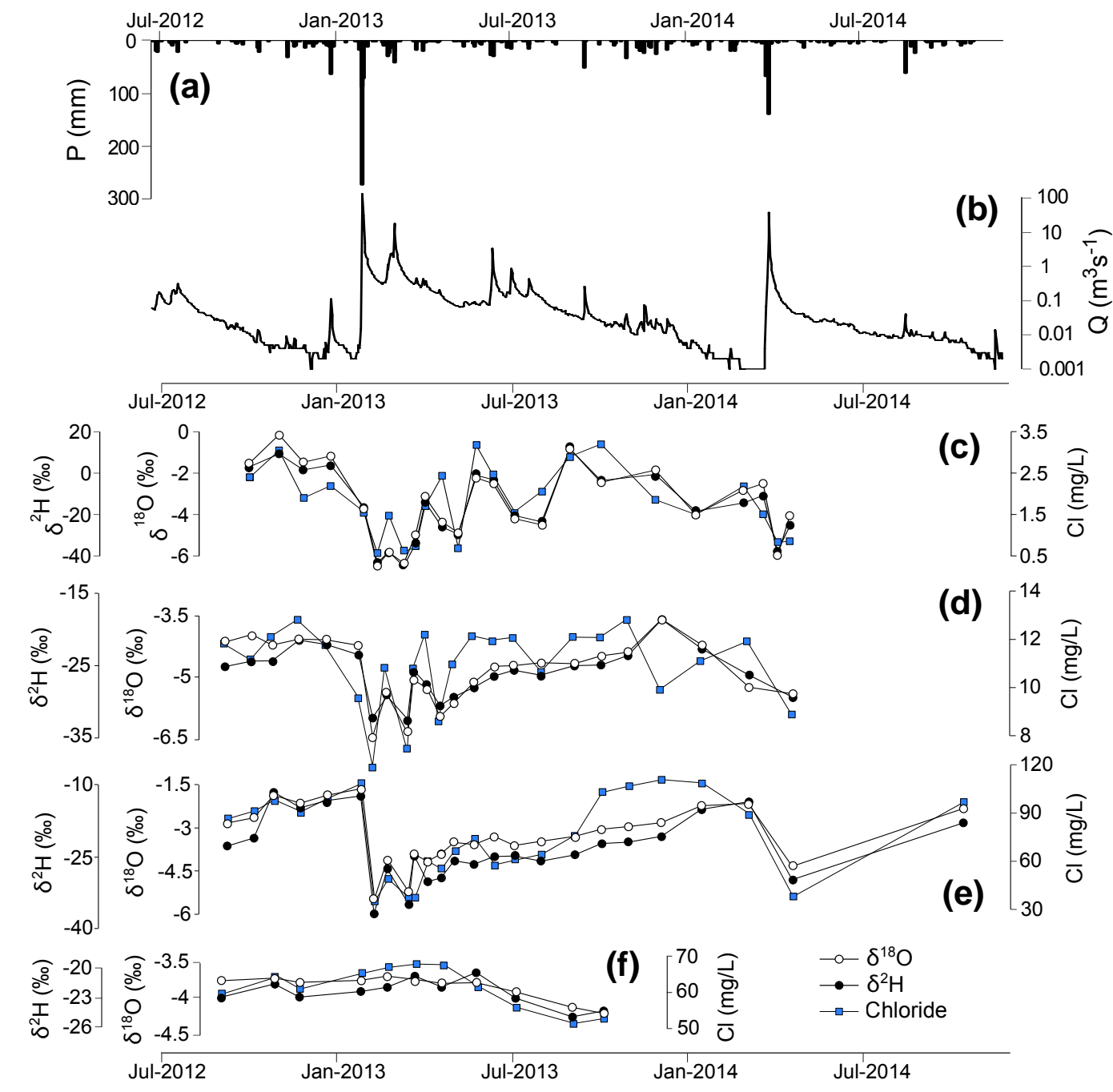

Figure 2. Time series of Thiessen-averaged precipitation (a), daily discharge at Croftby (DNRM station $145011 \mathrm{~A})(\mathbf{b})$, and $\delta^{2} \mathrm{H}, \delta^{18} \mathrm{O}$ and chloride at R1 (rainfall) (c), S1 (d) and S2 (streamwater) (e), and G1 (groundwater) (f). Note that the $y$ axes of $\delta^{2} \mathrm{H}, \delta^{18} \mathrm{O}$ and chloride have different scales for each individual plot.

position). An input recharge function was initially computed from the measured input data that accounts for loss due to evapotranspiration (e.g. Bergmann et al., 1986; Stewart and Thomas, 2008):

$C_{\mathrm{r}}(t)=\frac{R(t)}{\bar{R}}\left(C_{\mathrm{p}}(t)-\overline{C_{\mathrm{r}}}\right)+\overline{C_{\mathrm{r}}}$

where $C_{\mathrm{r}}(t)$ is the weighted input recharge signature at time $t ; \overline{C_{\mathrm{r}}}$ is the average recharge signature (taken at G1); $C_{\mathrm{p}}(t)$ is the input rainfall signature; $R(t)$ is the fortnightly recharge as calculated by the difference between precipitation and evapotranspiration; and $\bar{R}$ is the average recharge amount.

The weighted input was then convoluted to the selected TT distribution function $(g)$ to obtain output signatures (Mal- oszewski and Zuber, 1982):

$C_{\text {out }}(t)=\left[g \cdot C_{\mathrm{r}}\right](t)=\int_{0}^{\infty} C_{\mathrm{r}}\left(t-t_{\mathrm{e}}\right) g\left(t_{\mathrm{e}}\right) e^{\left(-\lambda t_{\mathrm{e}}\right)} \mathrm{d} t_{\mathrm{e}}$,

where $t_{\mathrm{e}}$ is time of entry; $C_{\mathrm{out}}(t)$ is the output signature; $C_{\mathrm{r}}(t)$ is the weighted input signature; $g\left(t_{e}\right)$ is an appropriate TT distribution function; and $e^{\left(-\lambda t_{\mathrm{e}}\right)}$ is the term that accounts for decay if a radioactive tracer is used $(\lambda=0$ for stable isotopes and chloride). In this study we used both the exponential and dispersion models; the reader is referred to Maloszewski and Zuber (1982) and Stewart and McDonnell (1991) for a detailed overview of TT distribution functions.

In some instances, two models were combined to represent more complex systems on the basis of our understanding of the catchment behaviour (Fig. 3). This was to distinguish be- 


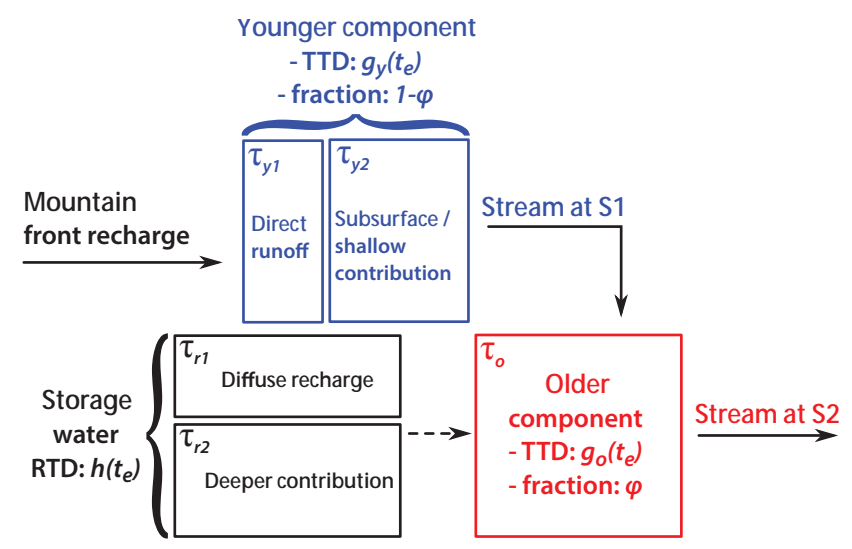

Figure 3. Conceptual diagram showing the flow components and their transit times to be characterised in this study.

tween a shallower and a deeper flow component with shorter and longer TT, respectively. Bimodal models were obtained by linearly combining two TT distributions:

$$
\begin{aligned}
& C_{\text {out }}(t)=\phi \int_{0}^{\infty} C_{\mathrm{r}}\left(t-t_{\mathrm{e}}\right) g_{\mathrm{o}}\left(t_{\mathrm{e}}\right) e^{\left(-\lambda t_{\mathrm{e}}\right)} \mathrm{d} t_{\mathrm{e}} \\
& +(1-\phi) \int_{0}^{\infty} C_{\mathrm{r}}\left(t-t_{\mathrm{e}}\right) g_{\mathrm{y}}\left(t_{\mathrm{e}}\right) e^{\left(-\lambda t_{\mathrm{e}}\right)} \mathrm{d} t_{\mathrm{e}}
\end{aligned}
$$

where $\phi$ is the fraction of the older component $(0<\phi<1)$, and $g_{\mathrm{o}}\left(t_{\mathrm{e}}\right)$ and $g_{\mathrm{y}}\left(t_{\mathrm{e}}\right)$ are the TT distribution functions of the older and younger components, respectively (Fig. 3). Bimodal distributions combined either two dispersion models or one exponential and one dispersion model. The mean TTs, noted $\tau$, were then derived from the fitted distributions by calculating their first moment:

$$
\tau=\int_{0}^{\infty} \operatorname{tg}(t) \mathrm{d} t .
$$

In the following the mean TT of the younger component is referred to as $\tau_{\mathrm{y}}$ (subdivided into $\tau_{\mathrm{y} 1}$ and $\tau_{\mathrm{y} 2}$ ), while the mean TT of the older component is referred to as $\tau_{\mathrm{o}}$, and the mean RT of storage groundwater is referred to as $\tau_{\mathrm{r}}$ (subdivided into $\tau_{\mathrm{r} 1}$ and $\tau_{\mathrm{r} 2}$ ) (Fig. 3).

For chloride, the measured input and output series were highly dissimilar due to the significant effect of evaporative enrichment in soils. To get around this issue, a correction factor was applied to the predictions obtained using Eqs. (2) and (3): $C_{\text {out }}(t)$ values were multiplied by $F=\frac{P}{(P-\mathrm{ET})}$ (i.e. ratio between precipitation and recharge over the preceding 12 months). The reasoning behind the use of this correction factor was that all chloride ions find their way through the soil, whereas much of the rainfall is evaporated off.

To estimate the fraction of older water that contributed to streamflow, a simple two-component hydrograph separation was carried out (Sklash and Farvolden, 1979) based on fortnightly data of each of the three seasonal tracers. This allowed one to obtain time-varying values of $\phi$ :

$\phi(t)=\frac{\delta_{\mathrm{S} 1}(t)-\delta_{\mathrm{R} 1}(t)}{\overline{\delta_{\mathrm{G} 1}}-\delta_{\mathrm{R} 1}(t)}$,

where $\delta_{\mathrm{S} 1}, \delta_{\mathrm{R} 1}$ and $\delta_{\mathrm{G} 1}$ are the tracer values of streamflow, rainfall and groundwater, respectively. The use of a chemical mass balance approach to partition streamflow was preferred over recursive digital filtering (Nathan and McMahon, 1990), because the former method is less likely to include delayed sources, such as bank return flow and/or interflow, in the older water component (Cartwright et al., 2014).

\subsubsection{Using tritium}

The occurrence of seasonal variations in rainfall ${ }^{3} \mathrm{H}$ concentrations has been widely documented (e.g. Stewart and Taylor, 1981; Tadros et al., 2014). These variations can be significant and have to be considered for achieving reliable estimates of TT distributions. Monthly ${ }^{3} \mathrm{H}$ precipitation data measured by ANSTO from bulk samples collected at Brisbane Aero were used to estimate the ${ }^{3} \mathrm{H}$ input function for the Teviot Brook catchment. Because Brisbane Aero is ca. $100 \mathrm{~km}$ north-east of Teviot Brook, the rainfall ${ }^{3} \mathrm{H}$ concentrations are likely to be significantly different between these two locations due to oceanic and altitudinal effects. According to Tadros et al. (2014), ${ }^{3} \mathrm{H}$ values for Toowoomba (i.e. located in the Great Dividing Range near Teviot Brook) were about $0.4 \mathrm{TU}$ above those for Brisbane Aero for the period 2005-2011. Based on this work, an increment of +0.4 TU was applied to values measured at Brisbane Aero in order to obtain a first estimate of rainfall ${ }^{3} \mathrm{H}$ concentrations for Teviot Brook (input series A2 in Table 1). A second estimate was obtained by comparing the historical ${ }^{3} \mathrm{H}$ data between Toowoomba and Brisbane Aero for the period with overlap between the two stations, i.e. 1968-1982. All monthly values with precipitation $>100 \mathrm{~mm}$, corresponding to rainfall likely contributing to recharge, were included in the analysis $(n=31)$. A scaling factor of 1.24 was derived from the correlation between the two stations $\left(R^{2}=0.80\right)$. This factor was used to compute input series B2 (Table 1).

To account for losses due to evapotranspiration as rainfall infiltrates into the ground, a weighting procedure similar to the one reported by Stewart et al. (2007) was developed. Monthly ${ }^{3} \mathrm{H}$ recharge was estimated by subtracting monthly evapotranspiration from monthly precipitation, and weighting the ${ }^{3} \mathrm{H}$ rainfall concentrations by the resulting recharge. Instead of calculating single annual values, 6-month and $1 \mathrm{yr}$ sliding windows were used to obtain monthly values as follows:

$$
C_{i}=\frac{\sum_{i-t}^{i} C_{j} r_{j}}{\sum_{i-t}^{i} r_{j}},
$$


Table 1. Description of the different ${ }^{3} \mathrm{H}$ input series computed for the Teviot Brook catchment.

\begin{tabular}{ll}
\hline Input series & Description of input parameters \\
\hline A1 & A2 $-25 \%$ \\
A2 & Brisbane Aero ${ }^{3} \mathrm{H}$ values $+0.4 \mathrm{TU}$ \\
A3 & A2 $+25 \%$ \\
B1 & B2 $-90 \%$ CI slope \\
B2 & Brisbane Aero ${ }^{3} \mathrm{H}$ values $\times 1.24 \mathrm{TU}$ \\
B3 & B2 $+90 \%$ CI slope \\
\hline
\end{tabular}

CI refers to the confidence interval on the Toowoomba vs. Brisbane Aero regression slope.

where $C_{i}$ is the monthly ${ }^{3} \mathrm{H}$ recharge for the $i$ th month, $C_{j}$ and $r_{j}$ are the monthly ${ }^{3} \mathrm{H}$ precipitation and monthly recharge rate for the $j$ th month, and $t$ is 6 or 12 depending on the span of the sliding interval used. To avoid edge effects, a Tukey filter (Tukey, 1968) with coefficient 0.6 was applied to the sliding windows.

Input (recharge) and output (streamwater) ${ }^{3} \mathrm{H}$ concentrations were then related using the same convolution integral as the one used for stable isotopes (Eqs. 2 and 3), with $\lambda$ the ${ }^{3} \mathrm{H}$ decay constant such that $\lambda=1.54 \times 10^{-4}$ day $^{-1}$. To account for the uncertainty in input parameters and to assess the sensitivity of TT distribution calculations to the input function, four additional input series were derived from A2 and B2 (Table 1), and all six input series were subsequently used in the calculations. Least square regressions were used, and root mean square errors (RMSE) were calculated to find the best data fit for each simulation using a trial and error process. All data processing and analyses were performed using Matlab version 8.4.0 (R2014b), with the Statistics toolbox version 9.1 .

\section{Results}

\subsection{Seasonal tracers in precipitation, streamwater and groundwater}

\subsubsection{Description}

Stable isotope ratios and chloride signatures in precipitation were highly variable throughout the study period (Figs. 2c and 4). The $\delta^{2} \mathrm{H}$ and $\delta^{18} \mathrm{O}$ rainfall values ranged between -41 and $+12 \%$ o (average $-12 \%$ ) and between -6.5 and $-0.1 \%$ (average $-3.1 \%$ ), respectively, while chloride concentrations ranged between 0.6 and $3.2 \mathrm{mgL}^{-1}$ (average $1.8 \mathrm{mgL}^{-1}$ ). Generally, the most significant rainfall events had isotopically depleted signatures. As an example, there was a considerable drop in all tracers during the January 2013 event (e.g. for $\delta^{2} \mathrm{H}$ : decrease from -16 to $-41 \%$; Fig. $2 \mathrm{c}$ ). The local meteoric water line derived from rainfall samples had an intercept of 15.8 and a slope of 8.4 (Duvert et al., 2015b), similar to that of Brisbane (Fig. 4a). The stable iso- tope ratios measured in streamwater at S1 (Fig. 2d) and S2 (Fig. 2e) also covered a wide range of values, and followed similar temporal patterns to those for rainfall. However, the overall variations were less pronounced in streamwater, with evident dampening of input signals. Average values were lower for $\mathrm{S} 1\left(\delta^{2} \mathrm{H}=-25\right.$ and $\delta^{18} \mathrm{O}=-4.9 \%$ ) than for $\mathrm{S} 2\left(\delta^{2} \mathrm{H}=-20\right.$ and $\left.\delta^{18} \mathrm{O}=-3.7 \% \circ\right)$, both locations having lower average values than rainfall. All S1 samples aligned close to the meteoric water line, whereas most S2 samples plotted along a linear trend to the right of the line (Fig. 4a). Chloride concentrations in streamwater ranged between 6.4 and $12.8 \mathrm{mg} \mathrm{L}^{-1}$ at $\mathrm{S} 1$, and between 35.1 and $111.1 \mathrm{mg} \mathrm{L}^{-1}$ at S2 (Figs. 2d and e, 4b). At S2, higher chloride values were consistent with higher $\delta^{18} \mathrm{O}$ values and vice versa, whereas there was a weaker correlation between the two tracers at S1 (Fig. 4b). The fluctuations in stable isotopes and chloride in groundwater were considerably attenuated as compared to rain and streamwater (Figs. 2f and 4). The $\delta^{2} \mathrm{H}$, $\delta^{18} \mathrm{O}$ and chloride values recorded at G1 tended to slightly decrease during the rainy season, although they stayed within the ranges $-22 \pm 3,-3.9 \pm 0.4 \%$ and $60 \pm 10 \mathrm{mgL}^{-1}$, respectively (Fig. 2f). Consistent displacement to the right of the meteoric line was observed for all G1 samples (Fig. 4a).

\subsubsection{Interpretation}

The large temporal variability observed in rainfall isotopic and chloride records (Fig. 2c) may be attributed to a combination of factors. First, there was an apparent seasonal cycle as values were higher in the dry season and tended to decrease during the wet season. These are well-known features for rainfall that can be related to the "amount effect" (Dansgaard, 1964) where raindrops during drier periods experience partial evaporation below the cloud base, typical in tropical to subtropical areas (Rozanski et al., 1993). Second, more abrupt depletions of ${ }^{2} \mathrm{H}$ and ${ }^{18} \mathrm{O}$ occurred during significant precipitation events (Fig. 2c), as has been reported in other parts of eastern Australia (Hughes and Crawford, 2013; King et al., 2015). In streamwater, isotopic ratios were generally lower for S1 and S2 than for rainfall, which most likely reflects the predominant contribution of depleted rainfall to recharge (Duvert et al., 2015b). Also, the position of S1 and S2 samples relative to the meteoric line (Fig. 4a) indicates that fractionation due to evaporation occurred at S2, because unlike those measured at S1, isotopic ratios measured at $\mathrm{S} 2$ followed a clear evaporation trend. Elevated chloride concentrations are further evidence of the occurrence of evaporative enrichment downstream, with values one order of magnitude higher at S2 than at S1 (Fig. 4b). These results are in line with field observations, showing that the streambed at S2 featured a gentler slope and that lateral inflows from evaporation-prone tributaries may have contributed to streamflow at this location. It can also be noted that the enrichment of chloride at S2 was much higher than that of stable isotopes (Fig. 4b). This is a common observa- 


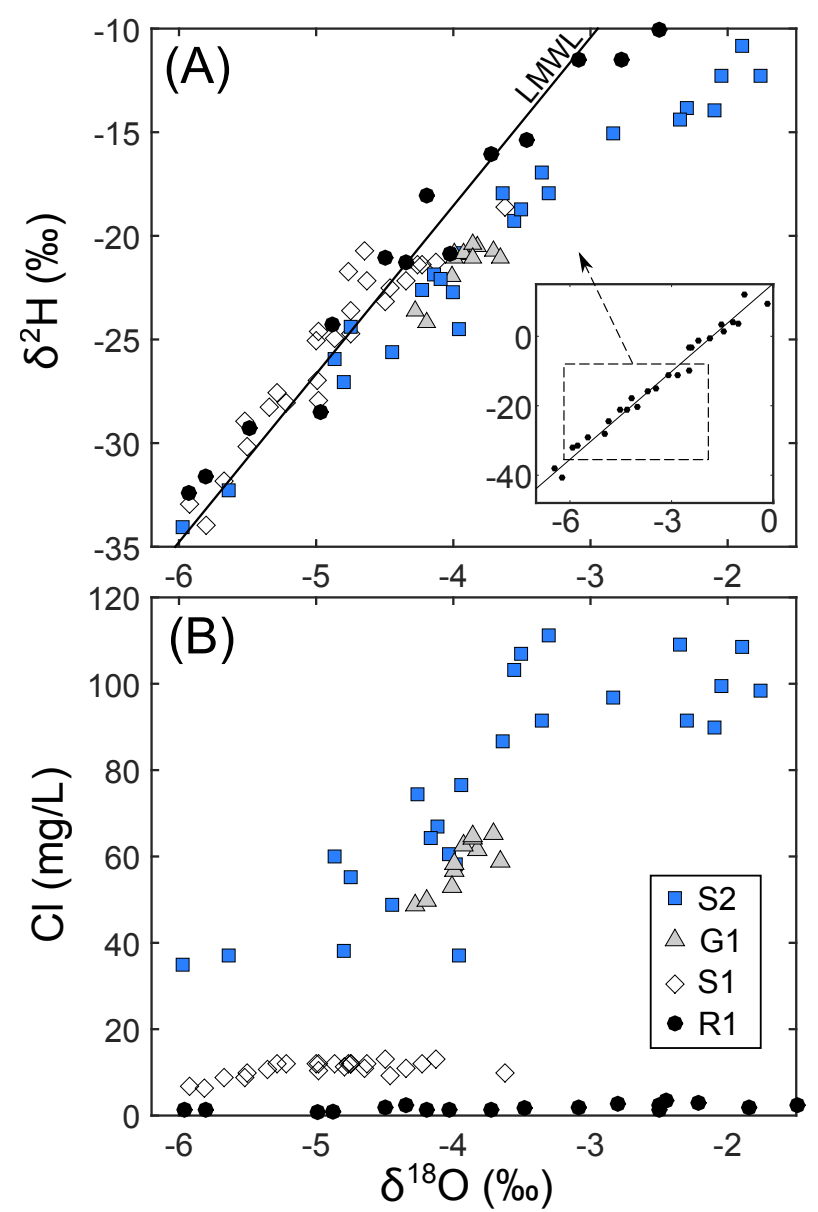

Figure 4. Relationships between (a) $\delta^{2} \mathrm{H}$ and $\delta^{18} \mathrm{O}$ and (b) chloride and $\delta^{18} \mathrm{O}$ for rainfall, streamwater and groundwater of the Teviot Brook catchment. The local meteoric water line plotted in (a) follows the equation $\delta^{2} \mathrm{H}=8.4 \cdot \delta^{18} \mathrm{O}+15.8$ (Duvert et al., 2015b). The eight $\mathrm{R} 1$ samples with $\delta^{18} \mathrm{O}$ values either $<-6.2 \%$ or $>-1.5 \%$ o are not shown in (b); chloride concentrations for these samples were in the range $0.6-3 \mathrm{mgL}^{-1}$.

tion in Australian catchments, largely attributed to high rates of evapotranspiration that concentrate cyclic salts in the unsaturated zone, thereby increasing the salinity of subsurface water before it discharges into streams (e.g. Allison et al., 1990; Cartwright et al., 2004; Bennetts et al., 2006).

\subsection{Tritium in precipitation, streamwater and groundwater}

\subsubsection{Description}

The groundwater sample collected at G1 in October 2012 yielded a ${ }^{3} \mathrm{H}$ activity of $1.07 \pm 0.06 \mathrm{TU}$. Additional data was obtained from Please et al. (1997), who collected a sample at the same location in 1994. This earlier sample had an activity of $1.80 \pm 0.20 \mathrm{TU}$. The 20 samples of streamwater collected
Table 2. Kendall's $\tau$ and Pearson's $r$ correlation coefficients between ${ }^{3} \mathrm{H}$ and other variables at $\mathrm{S} 2$.

\begin{tabular}{lrr}
\hline Variable & $r$ & $\tau$ \\
\hline Mean daily discharge $\left(\mathrm{m}^{3} \mathrm{~s}^{-1}\right)$ & 0.47 & 0.06 \\
$\delta^{2} \mathrm{H}(\% \circ)$ & -0.27 & -0.06 \\
$\delta^{18} \mathrm{O}(\% \circ)$ & -0.23 & 0.02 \\
$\mathrm{Cl}\left(\mathrm{mg} \mathrm{L}^{-1}\right)$ & -0.12 & 0.03 \\
$\mathrm{Si}\left(\mathrm{mg} \mathrm{L}^{-1}\right)$ & 0.35 & 0.11 \\
$\mathrm{Alkalinity}\left(\mathrm{mg} \mathrm{L}^{-1}\right)$ & -0.32 & -0.13 \\
$\mathrm{Fe}\left(\mathrm{mg} \mathrm{L}^{-1}\right)$ & 0.25 & 0.11 \\
Antecedent $P$ in the last 15 days $(\mathrm{mm})$ & 0.32 & -0.01 \\
Last day with $P>2$ mm (-) & 0.11 & 0.03 \\
\hline
\end{tabular}

No value was statistically significant at $p<0.05$ for both tests.

at $\mathrm{S} 2$ showed variable ${ }^{3} \mathrm{H}$ activities ranging between $1.16 \pm$ 0.06 and $1.43 \pm 0.06 \mathrm{TU}$ (Fig. 5).

In order to estimate a ${ }^{3} \mathrm{H}$ input signal for the Teviot Brook catchment, several precipitation time series were calculated from Brisbane Aero monthly ${ }^{3} \mathrm{H}$ data set, as detailed in Table 1 . Recharge time series were then derived from these precipitation time series using Eq. (6). An example of the calculated monthly precipitation and recharge time series for the 2003-2014 period is presented in Fig. 6 for scenario A2. While the ${ }^{3} \mathrm{H}$ activity in rainfall ranged between 1.1 and 6.4 TU for A2, most of the rainfall events contributing to recharge (i.e. for which monthly precipitation prevailed over monthly evapotranspiration; red circles in Fig. 6) remained in the narrower range $1.5-2.5 \mathrm{TU}$.

\subsubsection{Interpretation}

The ${ }^{3} \mathrm{H}$ activity in rainfall showed considerable month-tomonth variability. Winter (dry season) values generally were higher than summer (wet season) values, consistent with results from Tadros et al. (2014). Among the $20{ }^{3} \mathrm{H}$ values obtained at $\mathrm{S} 2$, higher values tended to coincide with higher flow conditions, although it was not systematic (Fig. 5). For instance, the sample collected in January 2013 under low flow conditions yielded $1.35 \pm 0.06 \mathrm{TU}$; by contrast, the sample collected in April 2014 during the falling limb of a major runoff event yielded $1.19 \pm 0.06 \mathrm{TU}$, i.e. among the lowest values on record. Kendall's rank correlation and Pearson's coefficients were calculated between the ${ }^{3} \mathrm{H}$ measurements in streamwater and other hydrological, hydrochemical and isotopic variables (Table 2). ${ }^{3} \mathrm{H}$ activity was not significantly correlated with any of the other variables. Unlike in Morgenstern et al. (2010) and Cartwright and Morgenstern (2015), there was no strong linear relationship between flow rate and ${ }^{3} \mathrm{H}$ activity in the stream. The lack of strong correlation between ${ }^{3} \mathrm{H}$ and variables such as antecedent wetness conditions and the number of days since the last high flow event occurred, implies that more complex mechanisms governed the short-term fluctuations of ${ }^{3} \mathrm{H}$ in streamwater. 


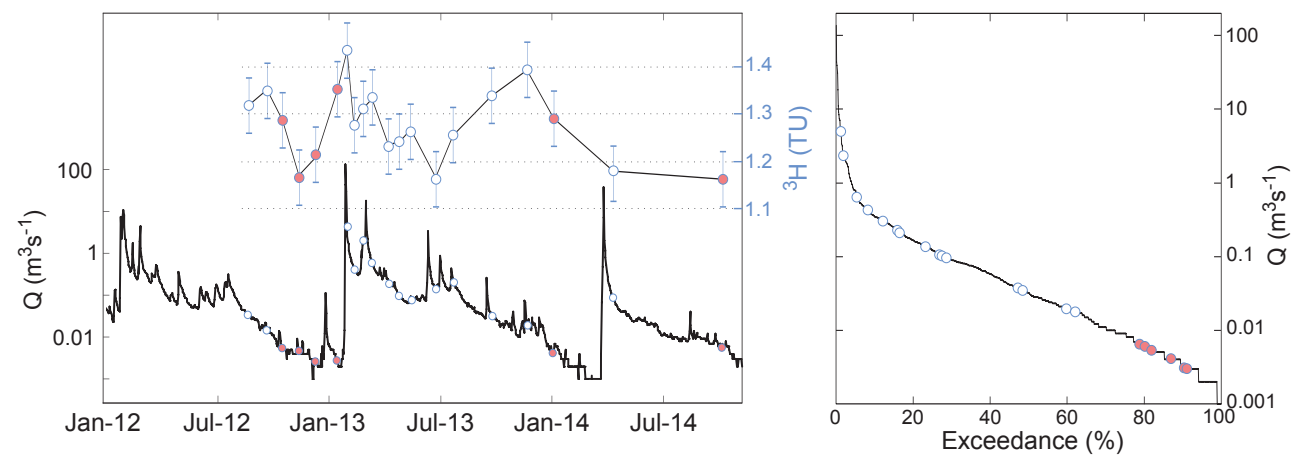

Figure 5. Time series of ${ }^{3} \mathrm{H}$ activity at $\mathrm{S} 2$ and daily discharge data (left). Flow duration curve at $\mathrm{S} 2$ (right). The six red circles correspond to samples used to fit the low baseflow model (see Fig. 9). The whiskers correspond to measurement uncertainty ( $\pm 0.06 \mathrm{TU}$ for all samples).

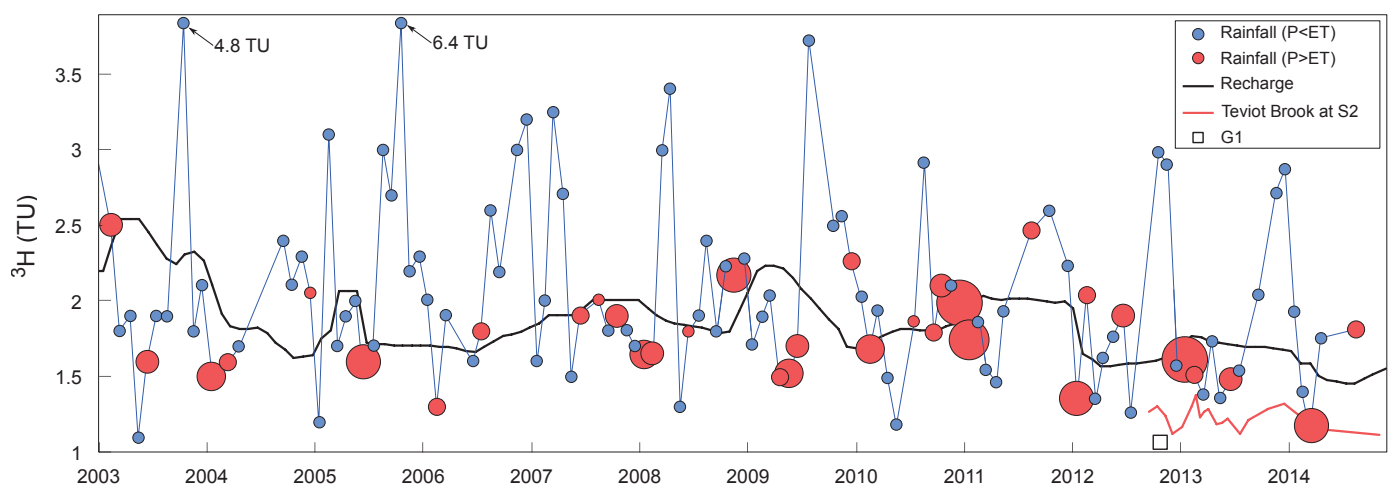

Figure 6. Temporal evolution of input ${ }^{3} \mathrm{H}$ in precipitation (circles) and recharge (black line) for the Teviot Brook catchment considering the A2 scenario. The plotted circles correspond to rainfall collected at Brisbane Aero and adjusted to Teviot Brook according to A2. The recharge time series was obtained using Eq. (6) and a 12-month sliding window. The marker size for rainfall contributing to recharge (red circles) reflects the recharge rate.

\subsection{Residence time estimate for storage water}

The sample collected at $\mathrm{G} 1$ in October $2012\left({ }^{3} \mathrm{H}=1.07 \pm\right.$ $0.06 \mathrm{TU})$ suggests that alluvial groundwater contains a substantial modern component, because its ${ }^{3} \mathrm{H}$ concentration was only slightly below that of modern rainfall. An earlier ${ }^{3} \mathrm{H}$ value reported by Please et al. (1997) was re-interpreted and combined with our more recent measurement to provide additional constraints on the RT at G1. Two steady-state models were adjusted to the data points. The first model to be tested was a unimodal dispersion model while the second one was a bimodal exponential-dispersion model. For the bimodal model, the mean RT of younger components $\tau_{\mathrm{r} 1}$ was constrained to 1 year, and the fraction of younger water was constrained to $57 \%$ as these parameters provided best fits on average.

Results for both models are presented in Table 3 and the two fits using A2 as an input function are shown in Fig. 7. As expected, mean RTs varied as a function of the input function chosen: values were generally lowest with A1 and B1 and highest with B3. Both models provided reasonably good fits, although for all simulations the bimodal distribu- tion described more accurately the measured data (median RMSE 0.04 vs. $0.20 \mathrm{TU}$; Table 3). Unimodal distributions had $\tau_{\mathrm{r}}$ ranging between 40 (using $\mathrm{A} 3$ as input series) and 62 years (using B2 as input series), with a standard deviation of 7 years among all simulations. The older water fraction of bimodal models had $\tau_{\mathrm{r} 2}$ between 76 (using $\mathrm{A} 1$ as input series) and 102 years (using B3 as input series), with a standard deviation of 9 years.

\subsection{Transit time estimates using seasonal tracers}

Lumped parameter models were adjusted to the stable isotope and chloride time series at S1. Due to the limited number of fortnightly data, all values were included in the analysis, i.e. samples collected under both low baseflow and higher flow conditions. Two models were tested and compared for this purpose, a unimodal exponential model and a bimodal exponential-dispersion model (Table 4; Fig. 8).

While both models provided reasonably low RMSE, unimodal models were less successful in capturing the highfrequency variations observed in output measurements (e.g. lowest values in late January and late February 2013; blue 
Table 3. Results of model simulations of residence time for $\mathrm{G} 1 \mathrm{using}{ }^{3} \mathrm{H}$.

\begin{tabular}{lcccrrrc}
\hline & \multicolumn{3}{c}{ Unimodal DM } & \multicolumn{4}{c}{ Bimodal EM-DM } \\
Input series & $\tau_{\mathrm{r}}$ (years) & $D_{\mathrm{P}}$ & $\mathrm{RMSE}(\mathrm{TU})$ & $\tau_{\mathrm{r} 1}$ (years) & $\tau_{\mathrm{r} 2}$ (years) & $D_{\mathrm{P}}$ & $\mathrm{RMSE}(\mathrm{TU})$ \\
\hline A1 & 46.9 & 0.70 & \pm 0.19 & 1 & 75.8 & 0.29 & \pm 0.02 \\
$\mathrm{~A} 2$ & 48.2 & 0.71 & \pm 0.18 & 1 & 82.9 & 0.30 & \pm 0.01 \\
$\mathrm{~A} 3$ & 39.8 & 0.71 & \pm 0.18 & 1 & 89.0 & 0.28 & \pm 0.03 \\
B1 & 48.5 & 0.69 & \pm 0.22 & 1 & 86.8 & 0.30 & \pm 0.06 \\
B2 & 61.6 & 0.70 & \pm 0.20 & 1 & 95.0 & 0.29 & \pm 0.05 \\
B3 & 54.6 & 0.69 & \pm 0.21 & 1 & 102.5 & 0.29 & \pm 0.05 \\
\hline
\end{tabular}

DM stands for dispersion model; EM-DM stands for exponential-dispersion model; $D_{\mathrm{P}}$ stands for dispersion parameter. For the $\mathrm{EM}-\mathrm{DM}, \tau_{\mathrm{r} 1}$ was constrained to 1 year, and the fraction of younger water was constrained to $57 \%$.

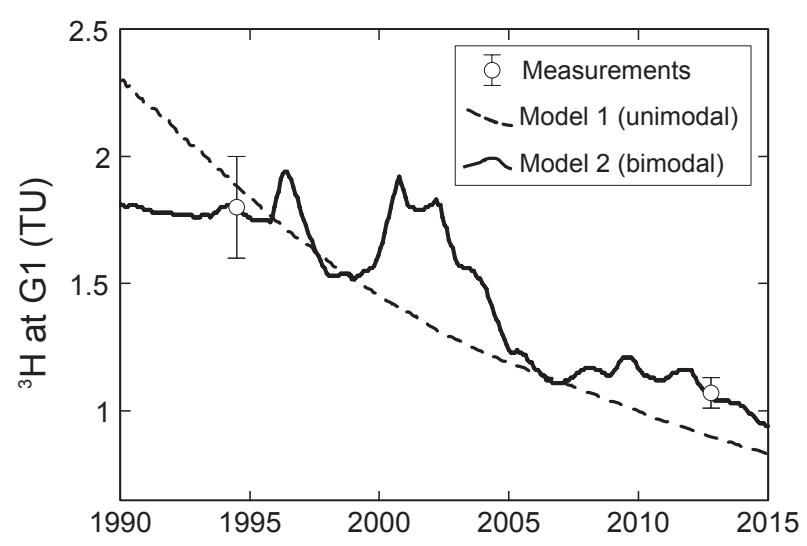

Figure 7. Fits of two models at $\mathrm{G} 1$ using $\mathrm{A} 2$ as input ${ }^{3} \mathrm{H}$ series. The unimodal model is a dispersion model with first moment 48.2 years and dispersion parameter 0.71 . The bimodal model is an exponential-dispersion model: a younger component (exponential distribution; fraction $57 \%$ ) with first moment 1 year and an older component (dispersion distribution; fraction 43\%) with first moment 82.9 years and dispersion parameter 0.30. The 1994 measurement is from Please et al. (1997).

lines in Fig. 8). All three tracers yielded comparable exponential TT distribution functions, with $\tau_{\mathrm{y}}$ ranging between 65 and 70 days (Table 4 ). The bimodal models provided slightly more satisfactory fits for all tracers (black lines in Fig. 8), with lower RMSE overall. Bimodal TT distribution functions derived from data at S1 had a younger fraction (27\%) with $\tau_{\mathrm{y} 1}$ between 14 and 16 days, and an older fraction $(73 \%)$ with $\tau_{\mathrm{y} 2}$ between 113 and 146 days (Table 4) depending on which tracer was used.

Calibration was also carried out on the tracer time series collected at S2 and following the same procedure (Table 4). When considering a unimodal exponential distribution, all three tracers yielded comparable TT distribution functions, with $\tau_{\mathrm{y}}$ ranging between 71 and 85 days, which was slightly longer than the mean TTs calculated at S1. When considering a bimodal exponential-dispersion distribution, the younger fraction had $\tau_{\mathrm{y} 1}$ of 23 to 24 days, while the older fraction had $\tau_{\mathrm{y} 2}$ of 99 to 109 days (Table 4 ).

\subsection{Transit time estimates using tritium}

\subsubsection{Model adjustment to low baseflow samples}

A lumped parameter model was fitted to the six ${ }^{3} \mathrm{H}$ samples that were taken under low baseflow conditions, i.e. $Q<$ $0.01 \mathrm{~m}^{3} \mathrm{~s}^{-1}$. The model chosen for this purpose was a bimodal exponential-dispersion model; the fitting procedure was as follows:

- The dispersion parameter of the older component was loosely constrained to around 0.3 in order to mimic the shape of the TT distribution identified at G1 (Sect. 4.3). The old water fraction $\phi$ was constrained to $82 \%$, i.e. the average value obtained for the six baseflow samples using tracer-based hydrograph separation following Eq. (5).

- Initial simulations were run using the six input series with no further model constraint. For the six scenarios, $\tau_{\mathrm{y}}$ consistently converged to $0.33 \pm 0.08$ years.

- All models were then re-run while adding the additional constraint as noted above, so that the only parameter to be determined by fitting was $\tau_{\mathrm{o}}$.

Figure 9 provides an example of the adjustment using A2 as input ${ }^{3} \mathrm{H}$ function. Reasonably good fits were obtained for all simulations $(0.14 \mathrm{TU}<\mathrm{RMSE}<0.16 \mathrm{TU})$, with $\tau_{\mathrm{o}}$ between 15.8 and 24.5 years, average $20.1 \pm 3.9$ years (Table 5).

\subsubsection{Model adjustment to single tritium values}

Unlike for rainfall ${ }^{3} \mathrm{H}$ values where high temporal variability was observed, the derived time series for recharge was relatively constant over the last decade (Fig. 6). This characteristic in principle allows reliable assessment of catchment TTs with single ${ }^{3} \mathrm{H}$ measurements, providing the ${ }^{3} \mathrm{H}$ remaining in the hydrosphere is too small to cause ambiguous ages, as it is in the Southern Hemisphere (Morgenstern et al., 2010; Stewart et al., 2010). All 20 samples collected at S2 were fitted separately using the same lumped model for each point, so that the only parameter to be determined by fitting was 

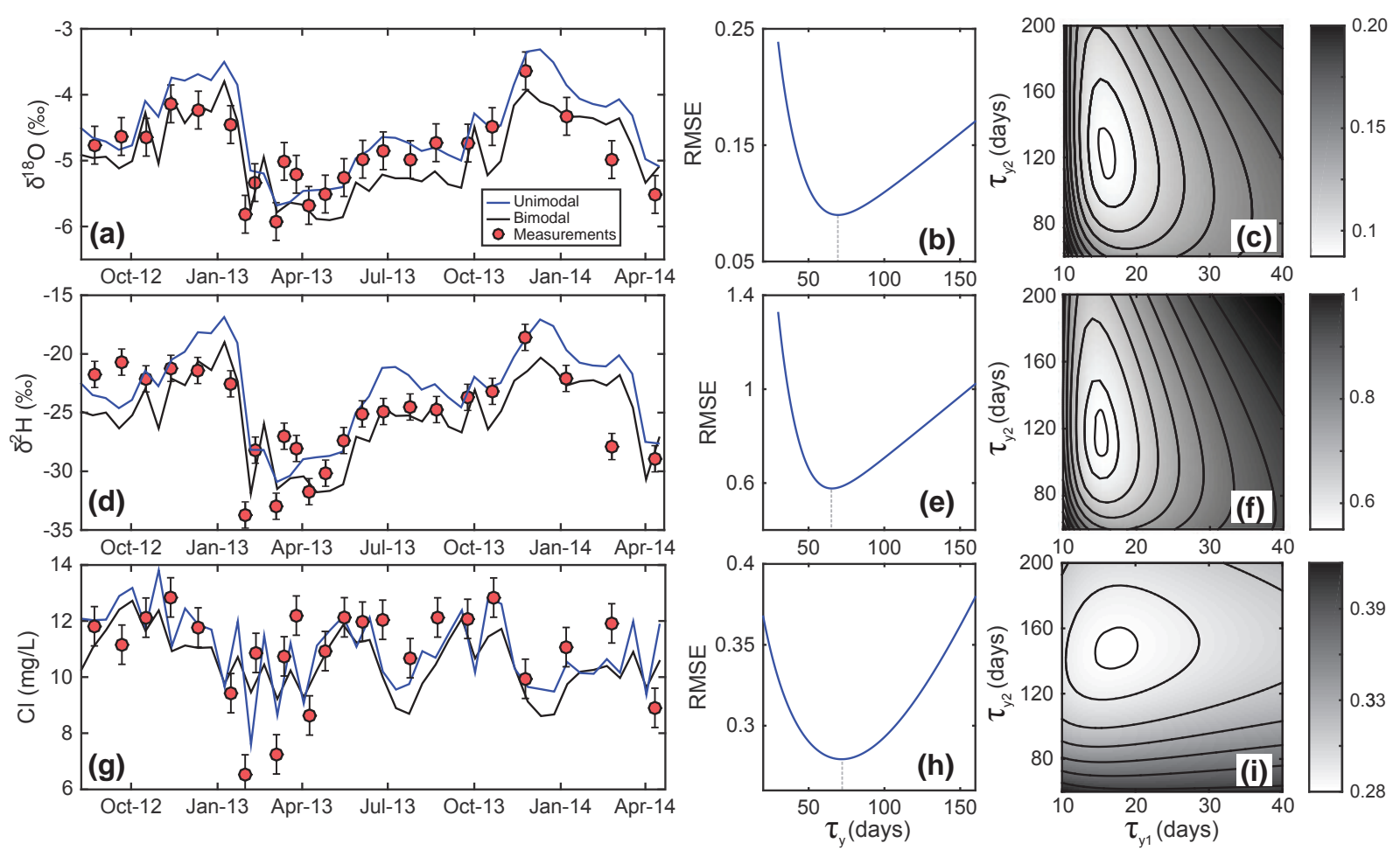

Figure 8. Exponential (blue) and exponential-dispersion (black) models calibrated to the $\delta^{18} \mathrm{O}(\mathbf{a}), \delta^{2} \mathrm{H}(\mathbf{d})$ and chloride (g) time series at $\mathrm{S} 1$. Whiskers correspond to the measurement uncertainty as given in the Methods section. Root mean square errors (RMSEs) of the exponential model as a function of $\tau_{\mathrm{y}}$ for the three tracers $(\mathbf{b}, \mathbf{e}, \mathbf{h})$. RMSE of the exponential-dispersion model (27\% younger component; dispersion parameter 0.3$)$ as a function of mean transit times of the younger $\left(\tau_{\mathrm{y} 1}\right)$ and older $\left(\tau_{\mathrm{y} 2}\right)$ fractions for the three tracers $(\mathbf{c}, \mathbf{f}$ and $\mathbf{i})$. Lighter colours are for lower RMSE, and the smallest contours correspond to the range of acceptable fit, arbitrarily defined as the values for which the RMSE are lower than the lowest RMSE obtained with the exponential models. Results for these simulations are reported in Table 4.

Table 4. Results of model simulations of transit time for $\mathrm{S} 1$ and $\mathrm{S} 2 \mathrm{using} \delta^{2} \mathrm{H}, \delta^{18} \mathrm{O}$ and chloride.

\begin{tabular}{|c|c|c|c|c|c|c|}
\hline \multirow[b]{2}{*}{ Sampling location } & \multirow[b]{2}{*}{ Tracer } & \multicolumn{2}{|c|}{ Unimodal EM } & \multicolumn{3}{|c|}{ Bimodal EM-DM } \\
\hline & & $\tau_{\mathrm{y}}$ (days) & RMSE & $\tau_{\mathrm{y} 1}$ (days) & $\tau_{\mathrm{y} 2}$ (days) & RMSE \\
\hline \multirow[t]{3}{*}{ S1 } & $\delta^{18} \mathrm{O}$ & 69 & $\pm 0.09 \%$ & 15 & 121 & $\pm 0.08 \%$ \\
\hline & $\delta^{2} \mathrm{H}$ & 65 & $\pm 0.58 \%$ & 15 & 113 & $\pm 0.52 \%$ \\
\hline & Chloride & 70 & $\pm 0.28 \mathrm{mg} \mathrm{L}^{-1}$ & 16 & 146 & $\pm 0.26 \mathrm{mg} \mathrm{L}^{-1}$ \\
\hline \multirow[t]{3}{*}{$\mathrm{S} 2$} & $\delta^{18} \mathrm{O}$ & 85 & $\pm 0.16 \%$ & 23 & 109 & $\pm 0.16 \%$ \\
\hline & $\delta^{2} \mathrm{H}$ & 71 & $\pm 0.75 \%$ & 24 & 99 & $\pm 0.72 \%$ \\
\hline & Chloride & 76 & $\pm 4.89 \mathrm{mg} \mathrm{L}^{-1}$ & 24 & 106 & $\pm 4.68 \mathrm{mg} \mathrm{L}^{-1}$ \\
\hline
\end{tabular}

EM stands for exponential model; EM-DM stands for exponential-dispersion model. For the EM-DM, the dispersion parameter of the second mode was 0.3 and the fraction of younger water was $27 \%$.

the TT of the old water fraction $\left(\tau_{\mathrm{o}}\right)$. The model parameters were chosen according to the best fit obtained for baseflow samples (i.e. mean TT of young component $\tau_{\mathrm{y}} 0.33$ years, dispersion parameter of old component 0.3; Sect. 4.5.1). In addition, for each sample the fraction of old water $\phi$ was constrained to the value obtained using tracer-based hydrograph separation according to Eq. (5). Conceptually, this approach appeared more meaningful than another option that would have consisted in constraining $\tau_{\mathrm{o}}$ and subsequently determining the old water fractions $\phi$, because there was no indication that $\tau_{\mathrm{o}}$ remained constant over time. Simulations were carried out for all three hydrograph separation tracers and all six input series, and the sensitivity of simulations to both the ${ }^{3} \mathrm{H}$ measurement uncertainty $( \pm 0.06 \mathrm{TU})$ and the error related to the hydrograph separation procedure were also calculated.

Time series of $\tau_{\mathrm{o}}$ were derived for each input function, and Fig. 10 shows the results obtained with A2 as an input series. The old water fraction $\phi$ varied between 0.39 and 1 , and while there was a good agreement between the three 


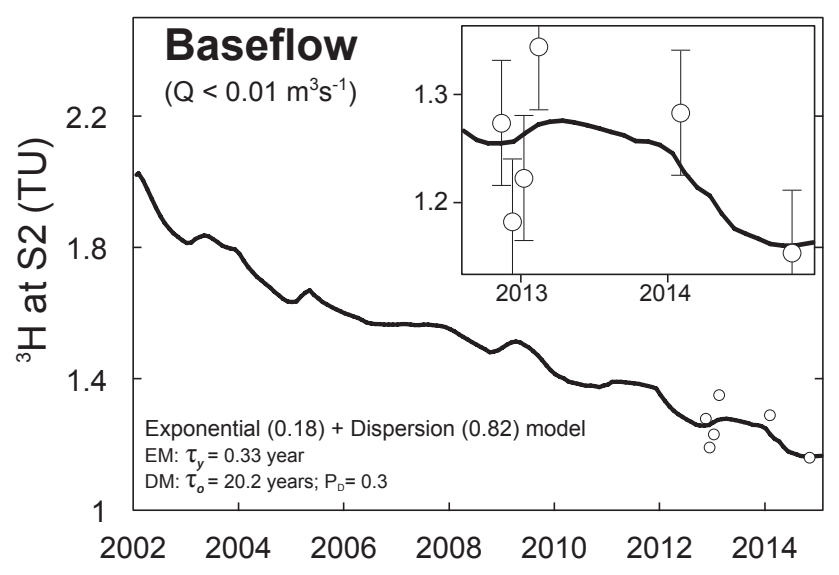

Figure 9. Bimodal model fitted to the ${ }^{3} \mathrm{H}$ activities at $\mathrm{S} 2$ under low baseflow conditions (i.e. daily $Q<0.01 \mathrm{~m}^{3} \mathrm{~s}^{-1}$ ). A2 was used as input ${ }^{3} \mathrm{H}$ series for this case. Results using other input series are listed in Table 5.

Table 5. Results of model simulations of transit time for $\mathrm{S} 2$ under low baseflow conditions (i.e. daily $Q<0.01 \mathrm{~m}^{3} \mathrm{~s}^{-1}$ ), using ${ }^{3} \mathrm{H}$ and an exponential-dispersion model.

\begin{tabular}{lcc}
\hline Input series & $\tau_{\mathrm{o}}$ (years) & RMSE (TU) \\
\hline A1 & 15.8 & \pm 0.15 \\
A2 & 20.2 & \pm 0.15 \\
A3 & 24.5 & \pm 0.15 \\
B1 & 15.8 & \pm 0.14 \\
B2 & 19.8 & \pm 0.16 \\
B3 & 24.4 & \pm 0.16 \\
\hline
\end{tabular}

The mean TT of younger components $\left(\tau_{\mathrm{y}}\right)$ was constrained to 0.33 years, the dispersion parameter of older components was constrained to 0.3 , and the ratio of older water was constrained to $82 \%$.

tracers, hydrograph separation based on chloride generally yielded lower variations in $\phi$ over time (Fig. 10a). Generally, the older component was lowest during high flow conditions and greatest during recession periods. The simulated $\tau_{\mathrm{o}}$ values varied considerably over time, and variations exceeded the uncertainties related to measurement uncertainties, chemical mass balance calculation errors and input estimates (Fig. 10b-d). ${ }^{18} \mathrm{O}$ was the least accurate in evaluating the variations in $\tau_{\mathrm{o}}$ (wider range for the red shaded area in Fig. 10c), while chloride was the most accurate despite less pronounced $\tau_{\mathrm{o}}$ variations (narrower range for the red shaded area in Fig. 10d). Yet, all three tracers provided comparable results, with a consistent shift in values either upwards or downwards. As a general rule, there was a negative correlation between $\phi$ and $\tau_{\mathrm{o}}$. When using $\mathrm{A} 2$ as input function, $\tau_{\mathrm{o}}$ fluctuated between 11.9 and 58.0 years $\left({ }^{2} \mathrm{H}\right.$; Fig. 10b), 11.6 and 63.2 years $\left({ }^{18} \mathrm{O}\right.$; Fig. $\left.10 \mathrm{c}\right)$ and 11.5 and 42.1 years (chloride; Fig. 10d). For clarity purposes the $\tau_{\mathrm{o}}$ values reported in the text do not consider errors related to measurement uncertainty. Values were highest after the major recharge events that occurred in January and February 2013, with $\tau_{\mathrm{o}}$ between 26.8 and 63.2 years in late February, and in April 2014, with $\tau_{\mathrm{o}}$ between 28.3 and 55.1 years. They were lowest during periods undergoing sustained low flow such as in September 2012 ( $\tau_{\mathrm{o}}$ between 11.6 years for ${ }^{18} \mathrm{O}$ and 13.1 years for $\left.{ }^{2} \mathrm{H}\right)$ and in September 2013 ( $\tau_{\mathrm{o}}$ between 11.5 years for chloride and 11.9 years for ${ }^{2} \mathrm{H}$ ). Of note is the timing of the highest $\tau_{\mathrm{o}}$ value in late February 2013, i.e. 1 month after the major recharge episode.

\section{Discussion}

\subsection{Conceptual framework}

According to our conceptual understanding of the upper Teviot Brook catchment, we have partitioned streamflow into two major components (Fig. 3). The first end-member represents the contribution of younger waters from rapid recharge through the highly fractured igneous rocks forming the mountain front, as outlined in previous studies (Duvert et al., 2015b, a). This younger component was further divided into (i) quick flow and (ii) relatively delayed contribution of waters seeping from the rock fractures (Fig. 3). We assume that the TTs of the younger end-member can be accurately described through analysis of the seasonal tracers' signal dampening. Waters originating from this component typically had low total dissolved solid (TDS) concentrations, although high Si concentrations at high flow.

The second end-member we postulate contains older waters derived from the aquifer stores located in the lowland section of the study area (Fig. 3). Specifically, these are waters discharging from both the alluvial aquifer and the underlying sedimentary bedrock aquifer. Although a distinction between the two groundwater stores would be ideal, the lack of clear differentiation between both water types led us to consider one single "older water" component. We assume that the TTs of the older end-member may be accurately described through ${ }^{3} \mathrm{H}$ data analysis. The ${ }^{3} \mathrm{H}$ activities in both aquifers were generally lower than those in surface water; the sedimentary bedrock aquifer had on average lower ${ }^{3} \mathrm{H}$ values than the alluvial aquifer, and waters from both aquifers had varying but generally high TDS concentrations (Duvert et al., 2015b). Furthermore, higher Fe concentrations were observed in the sedimentary bedrock waters shortly after recharge (Duvert et al., 2015a).

In the next sections of the discussion, a stepwise approach is followed to evaluate the accuracy of the conceptual model outlined above. In particular, the younger and older components in streamflow are assessed and discussed in Sect. 5.2 and 5.3, respectively. Section 5.4 considers the relationships between the older streamflow component and groundwater stored in the catchment. The variations over time of the TTs of the older component $\tau_{\mathrm{o}}$ are then quantified and elucidated (Sect. 5.5). Lastly, Sect. 5.6 addresses the limitations of the 


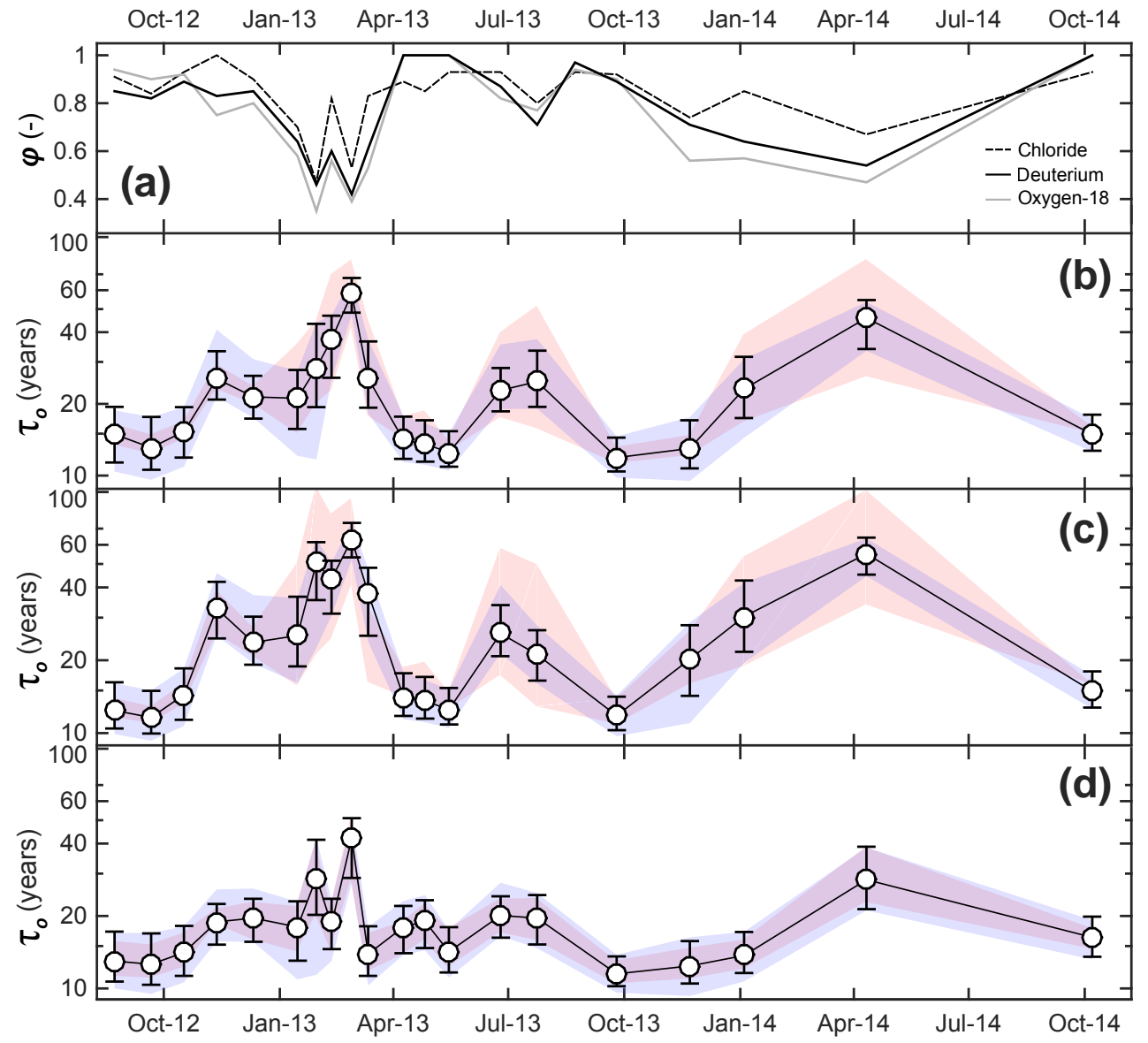

Figure 10. Variations in the older component fraction $\phi$ according to the three seasonal tracers (using Eq. (5)) (a). Variations in the TT of older fraction $\tau_{\mathrm{o}}$ at $\mathrm{S} 2$ based on hydrograph separation using ${ }^{2} \mathrm{H}(\mathbf{b}),{ }^{18} \mathrm{O}(\mathbf{c})$ and chloride (d). Values in (b-d) were obtained through the adjustment of exponential-dispersion models to each ${ }^{3} \mathrm{H}$ sample separately, and using A2 as input series and a 12-month sliding window. Whiskers represent the error range due to the measurement uncertainty on each sample (i.e. $\pm 0.06 \mathrm{TU}$ ). The blue shaded areas represent the range of values due to uncertainties in the estimation of recharge input (i.e. for the six ${ }^{3} \mathrm{H}$ input time series), while the red shaded areas represent the range of error related to the calculation of $\phi$, which was estimated according to the method described in Genereux (1998) and propagated to the calculation of $\tau_{\mathrm{O}}$.

current methodology and raises new questions for future research.

\subsection{Identification of a younger component in streamflow}

The younger end-member was defined by adjusting lumped models to the seasonal tracer time series (Sect. 4.4; Fig. 8). Among all the TT distributions described in the literature, the exponential model was selected because it considers all possible flowpaths to the stream - the shortest flowpath having a TT equal to zero and the longest having a TT equal to infinity (e.g. Stewart et al., 2010). Importantly, this distribution assumes heavy weighting of short flowpaths, which in our case may accurately replicate the prompt response of streamflow to rainfall inputs in the headwaters.

At S1, the bimodal distribution provided the most accurate simulations (Table 4), which lends support to the occurrence of two end-members contributing to streamflow at this upstream location. The first (exponential) component may reflect quick flow and subsurface waters feeding the stream ( $\tau_{\mathrm{y} 1}$ between 14 and 16 days), while the second (dispersion) component may be attributed to the contribution of waters discharging from the highly fractured igneous rocks ( $\tau_{\mathrm{y} 2}$ between 113 and 146 days; Fig. 8). Results at S2 were also slightly more accurate when using a bimodal distribution, suggesting a dual contribution to streamflow at S2 as well. More importantly, the fits for S2 were not as accurate as those for S1, regardless of the distribution and tracer used (Table 4). This reflects the likely importance of other concurrent processes in the downstream section of the catchment. Among them, evaporation may be a major limitation to applying steady-state lumped models at S2. It has been reported that ${ }^{18} \mathrm{O}$ is generally more sensitive to the effects of evaporation than ${ }^{2} \mathrm{H}$ (Klaus and McDonnell, 2013; Klaus et al., 
2015b). However, in this study there were no significant differences between TT distributions derived from the two stable isotopes. Calibration of the models on chloride measurements did not yield as accurate results as those for stable isotopes at $\mathrm{S} 1$ and to a higher extent at $\mathrm{S} 2$, which may be attributed to the higher effects of evaporative enrichment on chloride. Based on flux tracking methods, Hrachowitz et al. (2013) showed that processes such as evaporation can result in considerable biases in TT distribution estimates when using chloride as a tracer.

It is increasingly recognised that stable isotopes cannot provide realistic estimates of longer TT waters, regardless of the lumped model used (Stewart et al., 2012; Seeger and Weiler, 2014; Kirchner, 2015). In this study, it is very likely that older water (i.e. $>5$ years) contributed to streamflow at S2 (see Sect. 5.3) but also possibly at S1, and only using stable isotopes and chloride does not allow detection of such contribution. Therefore the ages defined above should be regarded as partial TTs that reflect the short-term and/or intermediate portions of the overall TT distribution for the system, i.e. $\tau_{\mathrm{y}}$ rather than $\tau$ (Seeger and Weiler, 2014).

\subsection{Identification of an older component in streamflow}

The transfer function that provided the most accurate estimates of TT for the baseflow samples at S2 was an exponential-dispersion model (Sect. 4.5.1). While other distributions could have been tested, there is a large body of literature that has reported good agreement between exponential, exponential-piston flow and dispersion models calibrated to ${ }^{3} \mathrm{H}$ data (e.g. Maloszewski et al., 1992; Herrmann et al., 1999; Stewart et al., 2007; Cartwright and Morgenstern, 2015). The good fits obtained using this bimodal function (Fig. 9; Table 5) confirm that two major water sources contributed to streamflow at S2. It can be argued that the exponential component captured all young contributions from upstream, i.e. quick flow + soil water + discharge from fractured igneous rocks, as identified in Sect. $5.2\left(\tau_{\mathrm{y}}=\right.$ 0.33 years), while the dispersion component encompassed the delayed groundwater flowpaths $\left(\tau_{\mathrm{o}}\right.$ between 15.8 and 24.5 years). This older contribution to streamflow may originate from the alluvial aquifer, potentially supplemented by seepage from the bedrock storage, as discussed in Sect. 5.1.

A number of studies were carried out in the last 4 decades that also used ${ }^{3} \mathrm{H}$ to assess TTs of the baseflow component to streams. For catchment areas in the range $10-200 \mathrm{~km}^{2}$, TT estimates were between 3 and 157 years $(n=39$; median 12 years; data presented in Stewart et al. (2010) supplemented with later papers by Morgenstern et al. (2010), Kralik et al. (2014) and Cartwright and Morgenstern (2015)). While our results compare relatively well to the literature, estimates can vary greatly even within single catchments (e.g. Morgenstern et al., 2010). Also, all reported studies were conducted in temperate regions, this work being the first one carried out in a subtropical setting.

\subsection{Storage water and its relationships with the older streamflow component}

Simulations of groundwater RT using ${ }^{3} \mathrm{H}$ as a tracer are generally insensitive to the type of lumped parameter model chosen, given that ambient ${ }^{3} \mathrm{H}$ levels are now almost at prebomb levels (e.g. Stewart and Thomas, 2008). At G1, better fits were obtained for bimodal functions (Fig. 7; Table 3). This may be interpreted as the probable partitioning of groundwater into one contribution of younger waters by diffuse recharge or flood-derived recharge $\left(\tau_{\mathrm{r} 1} \approx 1\right.$ year) coupled with a second contribution of older waters, potentially seeping from the underlying sedimentary bedrock aquifer ( $\tau_{\mathrm{r} 2} \approx 80$ to 100 years).

While the older component to streamflow as identified in Sect. 5.3 was characterised by relatively old waters with TT in the range 15.8-24.5 years, this contribution could not be directly related to the RT of storage waters (i.e. $\tau_{\mathrm{o}} \neq \tau_{\mathrm{r}}$ ). Despite the exclusive use of samples taken under low baseflow conditions to determine $\tau_{\mathrm{o}}$, the obtained values were significantly lower than the estimates of $\tau_{\mathrm{r} 2}$ for the alluvial aquifer (average $20.1 \pm 3.9$ vs. $88.7 \pm 9.3$ years, respectively). This confirms that water stored in the catchment (resident water) and water exiting the catchment (transit water) are fundamentally different and do not necessarily follow the same variations, as recognised in recent work (e.g. Hrachowitz et al., 2013; van der Velde et al., 2015). Results from a dynamic model of chloride transport revealed that water in transit was generally younger than storage water (Benettin et al., 2015). Differences between RTs and TTs also indicate that the assumption of complete mixing was not met for the Teviot Brook catchment. This corroborates the findings from van der Velde et al. (2015), who established that complete mixing scenarios resulted in incorrect TT estimates for a catchment subjected to high seasonal rainfall variability. For instance, shallow flowpaths may be activated or deactivated under varying storage. Among the few studies that investigated the relations between catchment TT and groundwater RT based on ${ }^{3} \mathrm{H}$ measurements, Matsutani et al. (1993) reported that streamwater was formed by a mixture of longer RT groundwater (19 years) and shorter RT soil water ( $<1$ year). Overall, more work is needed to better define the two distributions and to assess how they relate to each other under non-stationary storage conditions.

\subsection{Drivers of the variability in the older component transit time}

When fitting models to each ${ }^{3} \mathrm{H}$ value in streamwater, $\tau_{\mathrm{o}}$ was found to vary substantially over time (Fig. 10). In order to better apprehend the factors influencing the variations in $\tau_{0}$, the obtained values were compared to other hydrological and hydrochemical variables, particularly the antecedent wetness conditions, dissolved Fe concentrations and the old water discharge rate (Fig. 11). Under sustained dry 
conditions $\left(P_{15}<5 \mathrm{~mm}\right)$, there was no consistent relationship between $\tau_{\mathrm{o}}$ and the amount of precipitation during the 15 days prior to sampling, with $\tau_{\mathrm{o}}$ ranging between 14.9 and 23.1 years $\left(n=3\right.$; Fig. 11a). For higher values of $P_{15}$ (i.e. $\left.P_{15} \geq 10 \mathrm{~mm}\right)$, there was a positive correlation between the two variables $\left(n=17, R^{2}\right.$ for power law fit $=0.47$, $\mathrm{p}$-value $=0.002)$. The TT of the old water fraction was lowest for $P_{15}$ between 10 and $50 \mathrm{~mm}$ ( $\tau_{\mathrm{o}} 11.9$ to 25.5 years), and it increased when antecedent precipitation increased $\left(\tau_{\mathrm{o}} 25.6\right.$ to 58.0 years for $P_{15}>100 \mathrm{~mm}$ ). Generally, values averaged $17.0 \pm 5.6$ years at low flow and $38.3 \pm 14.7$ years after major high flow events. This was in accordance with results from Fig. 10, and suggestive of the predominant contribution of older alluvial and/or bedrock waters shortly after recharge episodes.

There was also a positive relationship between $\tau_{\mathrm{o}}$ and $\mathrm{Fe}$ concentrations at $\mathrm{S} 2\left(n=20, R^{2}\right.$ for power law fit $=0.48$, pvalue $=0.001$, with all the values $>0.2 \mathrm{mgL}^{-1}$ corresponding to $\tau_{\mathrm{o}}>30$ years (Fig. 11b). In contrast, no significant relationship was observed at $\mathrm{S} 1$, as $\mathrm{Fe}$ values at this station ranged between $<0.01$ and $0.96 \mathrm{mgL}^{-1}$. Duvert et al. (2015a) reported increasing Fe concentrations after a major recharge event for some groundwaters of the sedimentary bedrock. The increase in streamflow $\mathrm{Fe}$ might therefore be a result of enhanced discharge of these waters into the drainage network, which is coherent with older $\tau_{\mathrm{o}}$ values. However, other chemical parameters distinctive of the bedrock groundwaters did not produce a characteristic signature in streamflow during high flow conditions. Or else, high $\mathrm{Fe}$ concentrations may be simply due to higher weathering rates at higher flows, although this hypothesis disregards the high value measured for the April 2014 sample $\left(\mathrm{Fe}=4.15 \mathrm{mg} \mathrm{L}^{-1}\right)$ despite relatively low discharge $(Q=$ $\left.0.095 \mathrm{~m}^{3} \mathrm{~s}^{-1}\right)$.

As discussed previously, a modification in storage due to a change in recharge dynamics may have activated different groundwater flowpaths and hence water parcels with different RTs (Heidbüchel et al., 2013; van der Velde et al., 2015; Cartwright and Morgenstern, 2015). When the rate of recharge was highest, flushing out of waters located in the deeper, older bedrock aquifer may have been triggered by the resulting pressure wave propagation. By contrast, the relatively younger $\tau_{\mathrm{o}}$ observed during lower flow conditions may be attributed to waters that originate from shallower parts of the alluvium and/or from subsurface layers. This is reflected in the relationship between $\tau_{\mathrm{o}}$ and $Q_{\mathrm{o}}$, i.e. the portion of streamflow provided by the older component $\left(Q_{\mathrm{o}}=Q \cdot \phi\right.$; Fig. 11c). In this figure the groundwater end-member corresponds to $\tau_{\mathrm{r}}$ (using the highest recorded $Q_{\mathrm{o}}$ through the study period), while the baseflow end-member corresponds to the $\tau_{\mathrm{o}}$ value calculated using the six baseflow samples. The two end-members were linearly connected in an area that represents the extent of possible fluctuations of $\tau_{\mathrm{o}}$, from lower old water contributions to higher old water contributions. The individual $\tau_{\mathrm{o}}$ values broadly followed this mixing
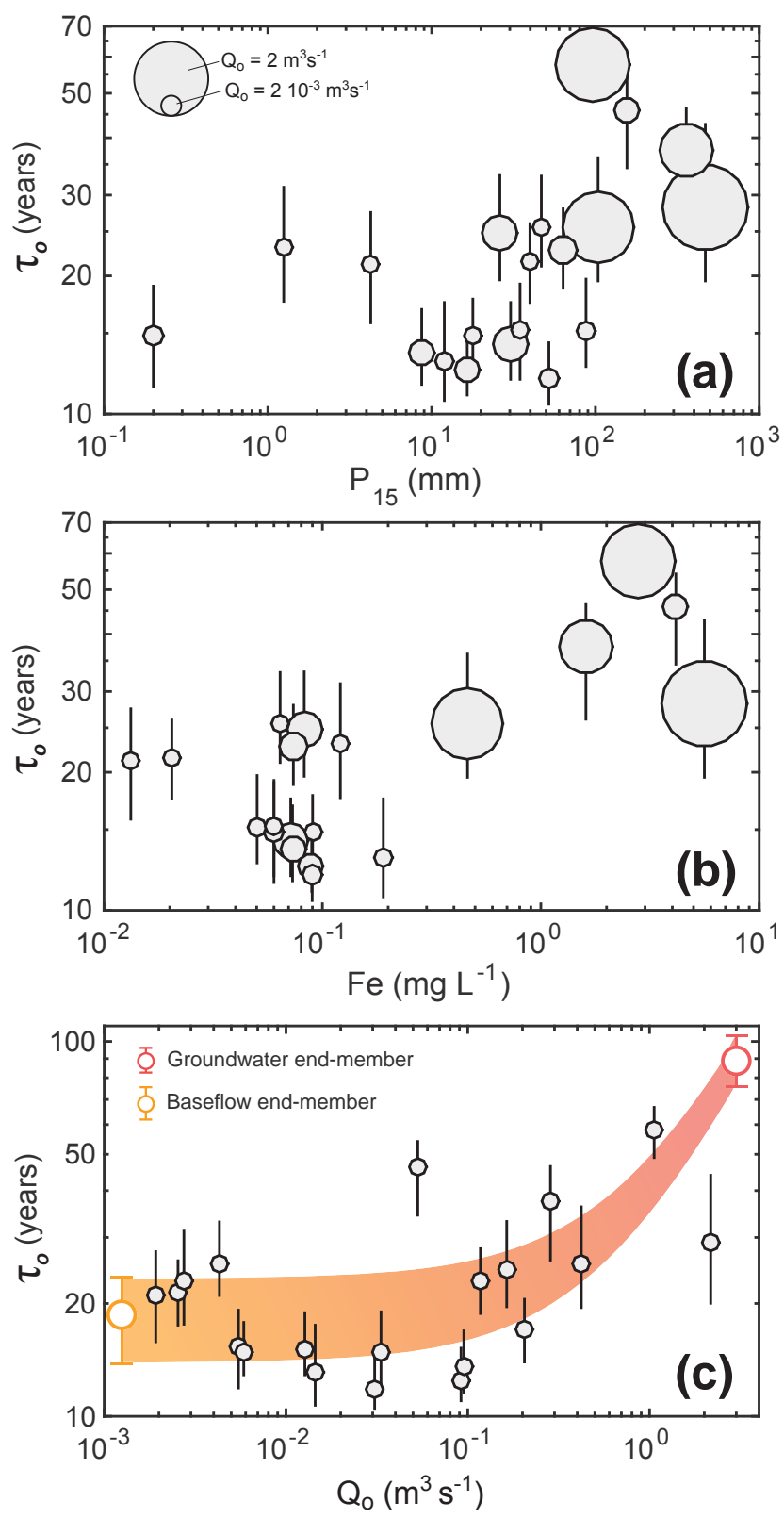

Figure 11. Relationship between the transit time of old water fraction $\left(\tau_{\mathrm{o}}\right)$ and antecedent precipitation $P_{15}$, i.e. precipitation depth over the catchment during the 15 days prior to sampling (a). Relationship between $\tau_{\mathrm{O}}$ and dissolved Fe concentrations (b). Relationship between $\tau_{\mathrm{o}}$ and $Q_{\mathrm{o}}\left(Q_{\mathrm{o}}=Q \cdot \phi\right)$ (c). Values were obtained using $\mathrm{A} 2$ as input series and ${ }^{2} \mathrm{H}$ as a hydrograph separation tracer. Whiskers correspond to simulations using upper and lower measurement uncertainty errors. The size of markers in (a) and (b) provides an indication on the value of $Q_{\mathrm{o}}$ during sampling. In (c), the groundwater (red) end-member corresponds to the RT calculated at G1, while the baseflow (orange) end-member corresponds to the TT of the old water fraction calculated at S2 using the six baseflow samples. The shaded area in (c) represents simple linear mixing between the two end-members. 
trend (Fig. 11c), which lends support to the assumptions that (i) the TT of the older end-member may not be characterised by a single value but rather by a range of possible ages that fluctuate depending on flow conditions, and (ii) during and shortly after higher flows, a near steady state was reached in which the TT of the old water fraction increased and approached the RT of stored water (i.e. $\tau_{\mathrm{o}} \rightarrow \tau_{\mathrm{r}}$ ). Overall, the large scattering observed in Fig. 11 suggests that many processes led to the variations in $\tau_{\mathrm{o}}$, and that these processes were largely non-linear.

Importantly, the finding that TTs of the old water component increased with increasing flow has not been reported before. Our results are in stark contrast with the previous observation by Morgenstern et al. (2010) and Cartwright and Morgenstern (2015) that ${ }^{3} \mathrm{H}$-derived TTs were higher at low flow conditions and lower at high flow conditions. However, these two studies did not account for a younger component to streamflow (i.e. $\phi$ was effectively constrained to 1 for all samples), which may explain the disagreement with our results. Hrachowitz et al. (2015) reported an increase in storage water RT at the start of the wet season in an agricultural catchment in French Brittany, which they related to changes in storage dynamics (i.e. more recent water bypassing storage at higher flow). The authors did not comment on potential changes in streamwater TT during the same period, however.

We also recognise that the results reported here might be due to partially incorrect interpretation of the obtained data set: underestimation of the old water fraction $\phi$ during high flow events might be responsible for the apparent positive correlation between $Q_{\mathrm{o}}$ and $\tau_{\mathrm{o}}$, although this is unlikely because the three seasonal tracers yielded very similar flow partitions. Another potential bias in our calculations is the possible lack of representation of the discharge from the fractured igneous rocks in the headwaters, which might contribute significantly to the young component during high flow events. Such enhanced contribution might result in slightly longer $\tau_{\mathrm{y}}$, hence shorter $\tau_{\mathrm{o}}$. Because no ${ }^{3} \mathrm{H}$ measurement was conducted at $\mathrm{S} 1$, this hypothesis could not be tested further (see Sect. 5.2). More generally, our work emphasises the current lack of understanding of the role and dynamics of deeper groundwater contributions to streams, and suggests that more multi-tracer data is needed to better assess the TTs of the old water fraction. Our findings also indicate that the so-called "old water fraction" (also referred to as "pre-event water" or "baseflow component" in tracer studies; e.g. Klaus and McDonnell, 2013; Stewart, 2015) should not be regarded as one single, time-invariant entity, but rather as a complex component made up of a wide range of flowpaths that can be hydrologically disconnected - and subsequently reactivated as recharge and flow conditions evolve.

\subsection{Limitations of this study and way forward}

Several assumptions have been put forward in this study that need to be carefully acknowledged. Firstly, there are limita- tions related to the use of seasonal tracers (i.e. stable isotopes and chloride):

1. The lumped convolution approach used for the assessment of TTs of the younger contribution to streamflow relied on assumptions of stationarity. Such assumptions are very likely not satisfied in headwater catchments, particularly those characterised by high responsiveness and high seasonal variability in their climate drivers ( $\mathrm{Ri}-$ naldo et al., 2011; McDonnell and Beven, 2014). Unfortunately, the data set obtained as part of this study did not enable characterisation of time-varying TT distribution functions, since this approach would require longer tracer records (e.g. Hrachowitz et al., 2013; Birkel et al., 2015) and/or higher sampling frequencies (e.g. Birkel et al., 2012; Benettin et al., 2013, 2015). Nonetheless, Seeger and Weiler (2014) recently noted that in the current state of research, the calculation of timeinvariant TT distributions from lumped models still represents a useful alternative to more complex, computerintensive modelling methods.

2. Using tracers that are notoriously sensitive to evapotranspiration in environments where this process commonly occurs can be problematic. Hrachowitz et al. (2013) established that evaporation can severely affect the calculations of TTs when chloride is used as an input-output tracer. Although evapotranspiration was considered in our recharge calculations (Eq. (1)), a detailed analysis of catchment internal processes would be needed to verify whether evapotranspiration modifies the storage water RTs and subsequent catchment TTs. Using data from a catchment subjected to high rainfall seasonal variability, van der Velde et al. (2015) showed that younger water was more likely to contribute to evapotranspiration, which tended to result in longer catchment TTs.

3. The partitioning of streamflow relied on the assumption that two main components contributed to streamwater, although this may not be the case at $\mathrm{S} 2$ because soil water may explain the higher chloride concentration and more enriched $\delta^{18} \mathrm{O}$ observed at this location (Klaus and McDonnell, 2013; Fig. 4). However, we hypothesise that the occurrence of this third end-member would not significantly affect the calculation of $\tau_{\mathrm{o}}$, because the TT of soil water is likely to be considerably shorter than that of the older streamflow component (e.g. Matsutani et al., 1993; Muñoz-Villers and McDonnell, 2012).

Secondly, there are a number of limitations related to the use of ${ }^{3} \mathrm{H}$ :

1. The most significant uncertainties were those related to the computed ${ }^{3} \mathrm{H}$ input functions. These may be reduced by regularly collecting rainfall ${ }^{3} \mathrm{H}$ on site. The accuracy of ${ }^{3} \mathrm{H}$ measurements was another source of uncertainty, 
and further improving analytical precision of ${ }^{3} \mathrm{H}$ activity in water samples may allow more rigorous assessment of short-term TT variations (e.g. Morgenstern and Daughney, 2012).

2. Changes in ${ }^{3} \mathrm{H}$ concentrations due to phase changes such as evaporation are commonly ignored, however, high evaporation environments such as that of the lower Teviot Brook catchment might significantly affect ${ }^{3} \mathrm{H}$ activity in streamwater. Future research is needed to examine more thoroughly the potential interferences on ${ }^{3} \mathrm{H}$ due to evaporation (Koster et al., 1989).

3. While stationarity may be a reasonable assumption for groundwater, inter-annual variations in recharge can affect RTs substantially (Manning et al., 2012). Further work aimed at providing additional constraints on RT variability is therefore required, by routinely collecting age tracer data in groundwater. Massoudieh et al. (2014a) showed that using multiple years of tracer records can allow more realistic quantification of the uncertainty on RT distributions. Also uncertain in our work is the spatial representativeness of waters collected at G1.

4. Despite yielding longer TTs than seasonal tracers, the use of ${ }^{3} \mathrm{H}$ did not preclude the potential omission of any older contribution (i.e. $>100$ years) to the stream. Frisbee et al. (2013) argued that even studies based on ${ }^{3} \mathrm{H}$ measurements might miss a significant part of the TT distributions rather than just their tail. In our case, the likelihood of waters with much longer RTs seeping from the sedimentary bedrock could not be verified using ${ }^{3} \mathrm{H}$ only. Other tracers that can capture older water footprints, such as terrigenic helium-4 (Smerdon et al., 2012) or carbon-14 (Bourke et al., 2014), would need to be tested for that purpose.

5. Another issue that has been raised recently is the potential aggregation biases affecting the calculation of TT distributions in complex systems (Kirchner, 2015). Based on the use of seasonal tracers, the author demonstrated that mean TTs are likely to be underestimated in heterogeneous catchments, i.e. those composed of subcatchments with contrasting TT distributions. A similar benchmark study should be undertaken for ${ }^{3} \mathrm{H}$ in order to verify whether TTs derived from ${ }^{3} \mathrm{H}$ measurements in heterogeneous catchments are also biased.

\section{Conclusions}

Based on time-series observations of seasonal tracers (stable isotopes and chloride) and ${ }^{3} \mathrm{H}$ in a subtropical mountainous catchment, we assessed the different contributions to streamflow as well as the variations in catchment TT and groundwater RT. Calibrating lumped parameter models to seasonal tracer data provided consistent estimates of TTs in the upstream part of the catchment, where evaporation was not a major process. In the downstream location, lumped models reproduced the tracers' output signals less accurately, partly because evapotranspiration complicated the input-output relationships, but also because of the increased hydrological complexity at this scale (i.e. interactions with deeper storage waters).

In this context, the use of ${ }^{3} \mathrm{H}$ time series was highly beneficial for (i) determining an older groundwater contribution to streamflow in the downstream area, and (ii) providing insight into the temporal variations of this old water fraction. The old water fraction TT was significantly younger than the RT of groundwater stored in the catchment, which outlines the necessary distinction between transit and storage waters in catchment process conceptualisation. When simulations were run separately on each ${ }^{3} \mathrm{H}$ streamwater sample, the TT of old water fraction was found to vary substantially over time, with values averaging $17 \pm 6$ years at low flow and $38 \pm 15$ years after major recharge events - other parameters being held constant. These variations were interpreted as the activation of longer, deeper flowpaths carrying older waters when the rate of recharge was highest.

Overall, this study suggests that collecting high-resolution ${ }^{3} \mathrm{H}$ data in streamwater can be valuable to document shortterm variations in the TT of old water fraction. If confirmed by further studies and corroborated by the use of other dating tracers, the occurrence of fluctuations in older contributions to streamflow may have important implications for water resource management and particularly contamination issues, because these fluctuations may control the timescales of retention and release of contaminants. It is therefore essential to collect longer-term experimental data that will contribute to identifying older groundwater contributions and to quantifying them with more confidence.

Acknowledgements. Funding for the tritium analyses was provided by the Australian Institute of Nuclear Science and Engineering (ALNGRA14026). Continuous financial support from the School of Earth, Environmental \& Biological Sciences and M. E. Cox (QUT) are greatly appreciated. We would like to thank A. Bonfanti, M. Citati, G. Destefano, J. López and C. Ranchoux for their assistance with fieldwork. R. Chisari (ANSTO) and J. Brady (QUT) carried out most laboratory analyses. The Brisbane Aero tritium rainfall data set was kindly provided by S. Hollins (ANSTO). Insightful discussion with S. Lamontagne (CSIRO) during the course of this study is gratefully acknowledged. D. Owen (QUT) is thanked for assistance with English. Comments by two anonymous reviewers and the Editor L. Pfister helped us improve the manuscript substantially. C. Duvert is supported by an Endeavour Scholarship (Australian Government).

Edited by: L. Pfister 


\section{References}

Allison, G. B., Cook, P. G., Barnett, S. R., Walker, G. R., Jolly, I. D., and Hughes, M. W.: Land clearance and river salinisation in the western Murray Basin, J. Hydrol., 119, 1-20, doi:10.1016/00221694(90)90030-2, 1990.

Benettin, P., van der Velde, Y., van der Zee, S. E. A. T. M., Rinaldo, A., and Botter, G.: Chloride circulation in a lowland catchment and the formulation of transport by travel time distributions, Water Resour. Res., 49, 4619-4632, doi:10.1002/wrcr.20309, 2013.

Benettin, P., Kirchner, J. W., Rinaldo, A., and Botter, G.: Modeling chloride transport using travel time distributions at Plynlimon, Wales, Water Resour. Res., 51, 3259-3276, doi:10.1002/2014WR016600, 2015.

Bennetts, D. A., Webb, J. A., Stone, D. J. M., and Hill, D. M.: Understanding the salinisation process for groundwater in an area of south-eastern Australia, using hydrochemical and isotopic evidence, J. Hydrol., 323, 178-192, doi:10.1016/j.jhydrol.2005.08.023, 2006.

Bergmann, H., Sackl, B., Maloszewski, P., and Stichler, W.: Hydrological investigation in a small catchment area using isotope data series, in: Fifth International Symposium on Underground Water Tracing, IAHS Publication no. 215, 255-272, Institute of Geology and Mineral Exploration, Athens (Greece), 1986.

Birkel, C., Soulsby, C., Tetzlaff, D., Dunn, S., and Spezia, L.: Highfrequency storm event isotope sampling reveals time-variant transit time distributions and influence of diurnal cycles, Hydrol. Process., 26, 308-316, doi:10.1002/hyp.8210, 2012.

Birkel, C., Soulsby, C., and Tetzlaff, D.: Conceptual modelling to assess how the interplay of hydrological connectivity, catchment storage and tracer dynamics controls nonstationary water age estimates, Hydrol. Process., 29, 2956-2969, doi:10.1002/hyp.10414, 2015.

Blavoux, B., Lachassagne, P., Henriot, A., Ladouche, B., Marc, V., Beley, J.-J., Nicoud, G., and Olive, P.: A fifty-year chronicle of tritium data for characterising the functioning of the Evian and Thonon (France) glacial aquifers, J. Hydrol., 494, 116-133, doi:10.1016/j.jhydrol.2013.04.029, 2013.

Bourke, S. A., Harrington, G. A., Cook, P. G., Post, V. E., and Dogramaci, S.: Carbon-14 in streams as a tracer of discharging groundwater, J. Hydrol., 519, 117-130, doi:10.1016/j.jhydrol.2014.06.056, 2014.

Burns, D. A., Murdoch, P. S., Lawrence, G. B., and Michel, R. L.: Effect of groundwater springs on NO3- concentrations during summer in Catskill Mountain streams, Water Resour. Res., 34, 1987-1996, doi:10.1029/98WR01282, 1998.

Cartwright, I. and Morgenstern, U.: Transit times from rainfall to baseflow in headwater catchments estimated using tritium: the Ovens River, Australia, Hydrol. Earth Syst. Sci., 19, 3771-3785, doi:10.5194/hess-19-3771-2015, 2015.

Cartwright, I., Weaver, T. R., Fulton, S., Nichol, C., Reid, M., and Cheng, X.: Hydrogeochemical and isotopic constraints on the origins of dryland salinity, Murray Basin, Victoria, Australia, Appl. Geochem., 19, 1233-1254, doi:10.1016/j.apgeochem.2003.12.006, 2004.

Cartwright, I., Gilfedder, B., and Hofmann, H.: Contrasts between estimates of baseflow help discern multiple sources of water contributing to rivers, Hydrol. Earth Syst. Sci., 18, 15-30, doi:10.5194/hess-18-15-2014, 2014.
Clark, I. D. and Fritz, P.: Environmental Isotopes in Hydrogeology, Lewis, New York, USA, 174-179, 1997.

Cook, P. and Solomon, D.: Recent advances in dating young groundwater: chlorofluorocarbons, ${ }^{3} \mathrm{H}^{3} \mathrm{He}$ and ${ }^{85} \mathrm{Kr}$, J. Hydrol., 191, 245-265, doi:10.1016/S0022-1694(96)03051-X, 1997.

Cvetkovic, V., Carstens, C., Selroos, J.-O., and Destouni, G.: Water and solute transport along hydrological pathways, Water Resour. Res., 48, W06537, doi:10.1029/2011WR011367, 2012.

Dansgaard, W.: Stable isotopes in precipitation, Tellus, 16, 436468, doi:10.1111/j.2153-3490.1964.tb00181.x, 1964.

Dunn, S. M., Birkel, C., Tetzlaff, D., and Soulsby, C.: Transit time distributions of a conceptual model: their characteristics and sensitivities, Hydrol. Process., 24, 1719-1729, doi:10.1002/hyp.7560, 2010.

Duvert, C., Cendón, D. I., Raiber, M., Seidel, J.-L., and Cox, M. E.: Seasonal and spatial variations in rare earth elements to identify inter-aquifer linkages and recharge processes in an Australian catchment, Chem. Geol., 396, 83-97, doi:10.1016/j.chemgeo.2014.12.022, 2015a.

Duvert, C., Raiber, M., Owen, D. D. R., Cendón, D. I., Batiot-Guilhe, C., and Cox, M. E.: Hydrochemical processes in a shallow coal seam gas aquifer and its overlying stream-alluvial system: implications for recharge and inter-aquifer connectivity, Appl. Geochem., 61, 146-159, doi:10.1016/j.apgeochem.2015.05.021, 2015b.

Einsiedl, F., Maloszewski, P., and Stichler, W.: Multiple isotope approach to the determination of the natural attenuation potential of a high-alpine karst system, J. Hydrol., 365, 113-121, doi:10.1016/j.jhydrol.2008.11.042, 2009.

Engdahl, N. B., Ginn, T. R., and Fogg, G. E.: Using groundwater age distributions to estimate the effective parameters of Fickian and non-Fickian models of solute transport, Adv. Water Resour., 54, 11-21, doi:10.1016/j.advwatres.2012.12.008, 2013.

Eriksson, E.: Compartment Models and Reservoir Theory, Ann. Rev. Ecol. Syst., 2, 67-84, doi:10.1146/annurev.es.02.110171.000435, 1971.

Freeze, R. A. and Cherry, J. A.: Groundwater, Prentice-Hall, Englewood Cliffs, USA, 136-137, 1979.

Frisbee, M. D., Wilson, J. L., Gomez-Velez, J. D., Phillips, F. M., and Campbell, A. R.: Are we missing the tail (and the tale) of residence time distributions in watersheds?, Geophys. Res. Lett., 40, 4633-4637, doi:10.1002/grl.50895, 2013.

Genereux, D.: Quantifying uncertainty in tracer-based hydrograph separations, Water Resour. Res., 34, 915-919, doi:10.1029/98WR00010, 1998.

Gröning, M., Lutz, H. O., Roller-Lutz, Z., Kralik, M., Gourcy, L., and Pöltenstein, L.: A simple rain collector preventing water re-evaporation dedicated for $\delta^{18} \mathrm{O}$ and $\delta^{2} \mathrm{H}$ analysis of cumulative precipitation samples, J. Hydrol., 448, 195-200, doi:10.1016/j.jhydrol.2012.04.041, 2012.

Gusyev, M. A., Toews, M., Morgenstern, U., Stewart, M., White, P., Daughney, C., and Hadfield, J.: Calibration of a transient transport model to tritium data in streams and simulation of groundwater ages in the western Lake Taupo catchment, New Zealand, Hydrol. Earth Syst. Sci., 17, 1217-1227, doi:10.5194/hess-171217-2013, 2013.

Harman, C. J.: Time-variable transit time distributions and transport: Theory and application to storage-dependent transport 
of chloride in a watershed, Water Resour. Res., 51, 1-30, doi:10.1002/2014WR015707, 2015.

Heidbüchel, I., Troch, P. A., Lyon, S. W., and Weiler, M.: The master transit time distribution of variable flow systems, Water Resour. Res., 48, W06520, doi:10.1029/2011WR011293, 2012.

Heidbüchel, I., Troch, P. A., and Lyon, S. W.: Separating physical and meteorological controls of variable transit times in zero-order catchments, Water Resour. Res., 49, 7644-7657, doi:10.1002/2012WR013149, 2013.

Herrmann, A., Bahls, S., Stichler, W., Gallart, F., and Latron, J.: Isotope hydrological study of mean transit times and related hydrogeological conditions in Pyrenean experimental basins (Vallcebre, Catalonia), in: Integrated methods in catchment hydrology - tracer, remote sensing, and new hydrometric techniques. Proceedings of IUGG 99 Symposium HS4, IAHS Publication no. 258, 101-110, International Association of Hydrological Sciences, Birmingham (UK), 1999.

Hrachowitz, M., Soulsby, C., Tetzlaff, D., Malcolm, I. A., and Schoups, G.: Gamma distribution models for transit time estimation in catchments: Physical interpretation of parameters and implications for time-variant transit time assessment, Water Resour. Res., 46, W10536, doi:10.1029/2010WR009148, 2010.

Hrachowitz, M., Savenije, H., Bogaard, T. A., Tetzlaff, D., and Soulsby, C.: What can flux tracking teach us about water age distribution patterns and their temporal dynamics?, Hydrol. Earth Syst. Sci., 17, 533-564, doi:10.5194/hess-17-533-2013, 2013.

Hrachowitz, M., Fovet, O., Ruiz, L., and Savenije, H. H. G.: Transit time distributions, legacy contamination and variability in biogeochemical 1/f $\alpha$ scaling: how are hydrological response dynamics linked to water quality at the catchment scale?, Hydrol. Process. 29, 5241-5256, doi:10.1002/hyp.10546, 2015.

Hughes, C. E. and Crawford, J.: Spatial and temporal variation in precipitation isotopes in the Sydney Basin, Australia, J. Hydrol., 489, 42-55, doi:10.1016/j.jhydrol.2013.02.036, 2013.

Katsuyama, M., Tani, M., and Nishimoto, S.: Connection between streamwater mean residence time and bedrock groundwater recharge/discharge dynamics in weathered granite catchments, Hydrol. Process., 24, 2287-2299, doi:10.1002/hyp.7741, 2010.

King, A. C., Raiber, M., Cendón, D. I., Cox, M. E., and Hollins, S. E.: Identifying flood recharge and inter-aquifer connectivity using multiple isotopes in subtropical Australia, Hydrol. Earth Syst. Sci., 19, 2315-2335, doi:10.5194/hess-19-23152015, 2015.

Kirchner, J. W.: Aggregation in environmental systems: seasonal tracer cycles quantify young water fractions, but not mean transit times, in spatially heterogeneous catchments, Hydrol. Earth Syst. Sci. Discuss., 12, 3059-3103, doi:10.5194/hessd-12-3059-2015, 2015.

Klaus, J. and McDonnell, J. J.: Hydrograph separation using stable isotopes: Review and evaluation, J. Hydrol., 505, 47-64, doi:10.1016/j.jhydrol.2013.09.006, 2013.

Klaus, J., Chun, K. P., McGuire, K. J., and McDonnell, J. J.: Temporal dynamics of catchment transit times from stable isotope data, Water Resour. Res., 51, 4208-4223, doi:10.1002/2014WR016247, 2015a.

Klaus, J., McDonnell, J. J., Jackson, C. R., Du, E., and Griffiths, N. A.: Where does streamwater come from in low-relief forested watersheds? A dual-isotope approach, Hydrol. Earth Syst. Sci., 19, 125-135, doi:10.5194/hess-19-125-2015, 2015b.

Koster, R. D., Broecker, W. S., Jouzel, J., Suozzo, R. J., Russell, G. L., Rind, D., and White, J. W. C.: The global geochemistry of bomb-produced tritium: General circulation model compared to available observations and traditional interpretations, J. Geophys. Res.-Atmos., 94, 18305-18326, doi:10.1029/JD094iD15p18305, 1989.

Kralik, M., Humer, F., Fank, J., Harum, T., Klammler, G., Gooddy, D., Sültenfuß, J., Gerber, C., and Purtschert, R.: Using ${ }^{18} \mathrm{O} /{ }^{2} \mathrm{H},{ }^{3} \mathrm{H} /{ }^{3} \mathrm{He},{ }^{85} \mathrm{Kr}$ and $\mathrm{CFCs}$ to determine mean residence times and water origin in the Grazer and Leibnitzer Feld groundwater bodies (Austria), Appl. Geochem., 50, 150-163, doi:10.1016/j.apgeochem.2014.04.001, 2014.

Lamontagne, S., Taylor, A. R., Batlle-Aguilar, J., Suckow, A., Cook, P. G., Smith, S. D., Morgenstern, U., and Stewart, M. K.: River infiltration to a subtropical alluvial aquifer inferred using multiple environmental tracers, Water Resour. Res., 51, 4532-4549, doi:10.1002/2014WR015663, 2015.

Leray, S., de Dreuzy, J.-R., Aquilina, L., Vergnaud-Ayraud, V., Labasque, T., Bour, O., and Borgne, T. L.: Temporal evolution of age data under transient pumping conditions, J. Hydrol., 511, 555-566, doi:10.1016/j.jhydrol.2014.01.064, 2014.

Maloszewski, P. and Zuber, A.: Determining the turnover time of groundwater systems with the aid of environmental tracers: 1. Models and their applicability, J. Hydrol., 57, 207-231, doi:10.1016/0022-1694(82)90147-0, 1982.

Maloszewski, P., Rauert, W., Trimborn, P., Herrmann, A., and Rau, R.: Isotope hydrological study of mean transit times in an alpine basin (Wimbachtal, Germany), J. Hydrol., 140, 343-360, doi:10.1016/0022-1694(92)90247-S, 1992.

Manning, A. H., Clark, J. F., Diaz, S. H., Rademacher, L. K., Earman, S., and Plummer, L. N.: Evolution of groundwater age in a mountain watershed over a period of thirteen years, J. Hydrol. 460-461, 13-28, doi:10.1016/j.jhydrol.2012.06.030, 2012.

Massoudieh, A.: Inference of long-term groundwater flow transience using environmental tracers: A theoretical approach, Water Resour. Res., 49, 8039-8052, doi:10.1002/2013WR014548, 2013.

Massoudieh, A., Leray, S., and de Dreuzy, J.-R.: Assessment of the value of groundwater age time-series for characterizing complex steady-state flow systems using a Bayesian approach, Appl. Geochem., 50, 240-251, doi:10.1016/j.apgeochem.2013.10.006, 2014a.

Massoudieh, A., Visser, A., Sharifi, S., and Broers, H. P.: A Bayesian modeling approach for estimation of a shape-free groundwater age distribution using multiple tracers, Appl. Geochem., 50, 252-264, doi:10.1016/j.apgeochem.2013.10.004, 2014b.

Matsutani, J., Tanaka, T., and Tsujimura, M.: Residence times of soil water, ground, and discharge waters in a mountainous headwater basin, central Japan, traced by tritium, in: Tracers in Hydrology, edited by Peters, N. E., Hoehn, E., Leibundgut, C., Tase, N., and Walling, D. E., IAHS Publication no. 215, 57-63, International Association for Hydrological Science, Wallingford (UK), 1993.

McCallum, J. L., Engdahl, N. B., Ginn, T. R., and Cook, P. G.: Nonparametric estimation of groundwater residence time distributions: What can environmental tracer data tell us about 
groundwater residence time?, Water Resour. Res., 50, 20222038, doi:10.1002/2013WR014974, 2014.

McDonnell, J. J. and Beven, K.: Debates - The future of hydrological sciences: A (common) path forward? A call to action aimed at understanding velocities, celerities and residence time distributions of the headwater hydrograph, Water Resour. Res., 50, 5342-5350, doi:10.1002/2013WR015141, 2014.

McDonnell, J. J., McGuire, K., Aggarwal, P., Beven, K. J., Biondi, D., Destouni, G., Dunn, S., James, A., Kirchner, J., Kraft, P., Lyon, S., Maloszewski, P., Newman, B., Pfister, L., Rinaldo, A., Rodhe, A., Sayama, T., Seibert, J., Solomon, K., Soulsby, C., Stewart, M., Tetzlaff, D., Tobin, C., Troch, P., Weiler, M., Western, A., Wörman, A., and Wrede, S.: How old is streamwater? Open questions in catchment transit time conceptualization, modelling and analysis, Hydrol. Process., 24, 1745-1754, doi:10.1002/hyp.7796, 2010.

McGuire, K. J. and McDonnell, J. J.: A review and evaluation of catchment transit time modeling, J. Hydrol., 330, 543-563, doi:10.1016/j.jhydrol.2006.04.020, 2006.

McGuire, K. J., McDonnell, J. J., Weiler, M., Kendall, C., McGlynn, B. L., Welker, J. M., and Seibert, J.: The role of topography on catchment-scale water residence time, Water Resour. Res., 41, W05002, doi:10.1029/2004WR003657, 2005.

McMillan, H., Tetzlaff, D., Clark, M., and Soulsby, C.: Do timevariable tracers aid the evaluation of hydrological model structure? A multimodel approach, Water Resour. Res., 48, W05501, doi:10.1029/2011WR011688, 2012.

Michel, R. L.: Tritium in the hydrologic cycle, in: Isotopes in the water cycle: past, present, and future of a developing science, edited by: Aggarwal, P. K., Gat, J. R., and Froehlich, K. F. O., 5366, Springer, Dordrecht The Netherlands, doi:10.1007/1-40203023-1, 2005.

Morgenstern, U. and Daughney, C. J.: Groundwater age for identification of baseline groundwater quality and impacts of land-use intensification - The National Groundwater Monitoring Programme of New Zealand, J. Hydrol., 456-457, 79-93, doi:10.1016/j.jhydrol.2012.06.010, 2012.

Morgenstern, U., Stewart, M. K., and Stenger, R.: Dating of streamwater using tritium in a post nuclear bomb pulse world: continuous variation of mean transit time with streamflow, Hydrol. Earth Syst. Sci., 14, 2289-2301, doi:10.5194/hess-14-22892010, 2010.

Mueller, M. H., Weingartner, R., and Alewell, C.: Importance of vegetation, topography and flow paths for water transit times of base flow in alpine headwater catchments, Hydrol. Earth Syst. Sci., 17, 1661-1679, doi:10.5194/hess-17-1661-2013, 2013.

Muñoz-Villers, L. E. and McDonnell, J. J.: Runoff generation in a steep, tropical montane cloud forest catchment on permeable volcanic substrate, Water Resour. Res., 48, W09528, doi:10.1029/2011WR011316, 2012.

Nathan, R. J. and McMahon, T. A.: Evaluation of automated techniques for base flow and recession analyses, Water Resour. Res., 26, 1465-1473, doi:10.1029/WR026i007p01465, 1990.

Penna, D., Stenni, B., Šanda, M., Wrede, S., Bogaard, T. A., Michelini, M., Fischer, B. M. C., Gobbi, A., Mantese, N., Zuecco, G., Borga, M., Bonazza, M., Sobotková, M., Čejková, B., and Wassenaar, L. I.: Technical Note: Evaluation of between-sample memory effects in the analysis of $\delta^{2} \mathrm{H}$ and $\delta^{18} \mathrm{O}$ of water sam- ples measured by laser spectroscopes, Hydrol. Earth Syst. Sci., 16, 3925-3933, doi:10.5194/hess-16-3925-2012, 2012.

Please, P. M., Bauld, J., and Watkins, K. L.: A groundwater quality assessment of the alluvial aquifers in the Logan-Albert catchment, SE Queensland, Tech. Rep. 1996/048, Australian Geological Survey Organisation, Canberra (Australia), 1997.

Plummer, L., Busenberg, E., Böhlke, J., Nelms, D., Michel, R., and Schlosser, P.: Groundwater residence times in Shenandoah National Park, Blue Ridge Mountains, Virginia, USA: a multitracer approach, Chem. Geol., 179, 93-111, doi:10.1016/S00092541(01)00317-5, 2001.

Reddy, M. M., Schuster, P., Kendall, C., and Reddy, M. B.: Characterization of surface and ground water $\delta^{18} \mathrm{O}$ seasonal variation and its use for estimating groundwater residence times, Hydrol. Process., 20, 1753-1772, doi:10.1002/hyp.5953, 2006.

Rinaldo, A., Beven, K. J., Bertuzzo, E., Nicotina, L., Davies, J., Fiori, A., Russo, D., and Botter, G.: Catchment travel time distributions and water flow in soils, Water Resour. Res., 47, W07537, doi:10.1029/2011WR010478, 2011.

Roa-García, M. C. and Weiler, M.: Integrated response and transit time distributions of watersheds by combining hydrograph separation and long-term transit time modeling, Hydrol. Earth Syst. Sci., 14, 1537-1549, doi:10.5194/hess-14-1537-2010, 2010.

Rodgers, P., Soulsby, C., Waldron, S., and Tetzlaff, D.: Using stable isotope tracers to assess hydrological flow paths, residence times and landscape influences in a nested mesoscale catchment, Hydrol. Earth Syst. Sci., 9, 139-155, doi:10.5194/hess-9-139-2005, 2005.

Rozanski, K., Araguás-Araguás, L., and Gonfiantini, R.: Isotopic Patterns in Modern Global Precipitation, in: Climate Change in Continental Isotopic Records, edited by Swart, P. K., Lohman, K. C., McKenzie, J., and Savin, S., 1-36, American Geophysical Union, Washington D.C., USA, doi:10.1029/GM078p0001, 1993.

Seeger, S. and Weiler, M.: Reevaluation of transit time distributions, mean transit times and their relation to catchment topography, Hydrol. Earth Syst. Sci., 18, 4751-4771, doi:10.5194/hess-184751-2014, 2014.

Sklash, M. G. and Farvolden, R. N.: Role of groundwater in storm runoff, J. Hydrol., 43, 45-65, doi:10.1016/0022-1694(79)90164$1,1979$.

Smerdon, B. D., Gardner, W. P., Harrington, G. A., and Tickell, S. J.: Identifying the contribution of regional groundwater to the baseflow of a tropical river (Daly River, Australia), J. Hydrol., 464465, 107-115, doi:10.1016/j.jhydrol.2012.06.058, 2012.

Soulsby, C., Malcolm, R., Helliwell, R., Ferrier, R. C., and Jenkins, A.: Isotope hydrology of the Allt a' Mharcaidh catchment, Cairngorms, Scotland: implications for hydrological pathways and residence times, Hydrol. Process., 14, 747-762, 2000.

Stewart, M. K.: A 40-year record of carbon-14 and tritium in the Christchurch groundwater system, New Zealand: Dating of young samples with carbon-14, J. Hydrol., 430-431, 50-68, doi:10.1016/j.jhydrol.2012.01.046, 2012.

Stewart, M. K.: Promising new baseflow separation and recession analysis methods applied to streamflow at Glendhu Catchment, New Zealand, Hydrol. Earth Syst. Sci., 19, 2587-2603, doi:10.5194/hess-19-2587-2015, 2015. 
Stewart, M. K. and McDonnell, J. J.: Modeling base flow soil water residence times from deuterium concentrations, Water Resour. Res., 27, 2681-2693, doi:10.1029/91WR01569, 1991.

Stewart, M. K. and Taylor, C. B.: Environmental isotopes in New Zealand hydrology; 1. Introduction. The role of oxygen-18, deuterium, and tritium in hydrology, New Zeal. J. Sci., 24, 295-311, 1981.

Stewart, M. K. and Thomas, J. T.: A conceptual model of flow to the Waikoropupu Springs, NW Nelson, New Zealand, based on hydrometric and tracer $\left({ }^{18} \mathrm{O}, \mathrm{Cl},{ }^{3} \mathrm{H}\right.$ and $\left.\mathrm{CFC}\right)$ evidence, Hydrol. Earth Syst. Sci., 12, 1-19, doi:10.5194/hess-12-1-2008, 2008.

Stewart, M. K., Mehlhorn, J., and Elliott, S.: Hydrometric and natural tracer (oxygen-18, silica, tritium and sulphur hexafluoride) evidence for a dominant groundwater contribution to Pukemanga Stream, New Zealand, Hydrol. Process., 21, 3340-3356, doi:10.1002/hyp.6557, 2007.

Stewart, M. K., Morgenstern, U., and McDonnell, J. J.: Truncation of stream residence time: how the use of stable isotopes has skewed our concept of streamwater age and origin, Hydrol. Process., 24, 1646-1659, doi:10.1002/hyp.7576, 2010.

Stewart, M. K., Morgenstern, U., McDonnell, J. J., and Pfister, L.: The 'hidden streamflow' challenge in catchment hydrology: a call to action for stream water transit time analysis, Hydrol. Process., 26, 2061-2066, doi:10.1002/hyp.9262, 2012.

Stolp, B. J., Solomon, D. K., Suckow, A., Vitvar, T., Rank, D., Aggarwal, P. K., and Han, L. F.: Age dating base flow at springs and gaining streams using helium-3 and tritium: Fischa-Dagnitz system, southern Vienna Basin, Austria, Water Resour. Res., 46, W07503, doi:10.1029/2009WR008006, 2010.

Tadros, C. V., Hughes, C. E., Crawford, J., Hollins, S. E., and Chisari, R.: Tritium in Australian precipitation: A 50 year record, J. Hydrol., 513, 262-273, doi:10.1016/j.jhydrol.2014.03.031, 2014.

Tetzlaff, D., Seibert, J., and Soulsby, C.: Inter-catchment comparison to assess the influence of topography and soils on catchment transit times in a geomorphic province; the Cairngorm mountains, Scotland, Hydrol. Process., 23, 1874-1886, doi:10.1002/hyp.7318, 2009.
Tetzlaff, D., Soulsby, C., Hrachowitz, M., and Speed, M.: Relative influence of upland and lowland headwaters on the isotope hydrology and transit times of larger catchments, J. Hydrol., 400, 438-447, doi:10.1016/j.jhydrol.2011.01.053, 2011.

Tetzlaff, D., Birkel, C., Dick, J., Geris, J., and Soulsby, C.: Storage dynamics in hydropedological units control hillslope connectivity, runoff generation, and the evolution of catchment transit time distributions, Water Resour. Res., 50, 969-985, doi:10.1002/2013WR014147, 2014.

Timbe, E., Windhorst, D., Crespo, P., Frede, H.-G., Feyen, J., and Breuer, L.: Understanding uncertainties when inferring mean transit times of water trough tracer-based lumped-parameter models in Andean tropical montane cloud forest catchments, Hydrol. Earth Syst. Sci., 18, 1503-1523, doi:10.5194/hess-18-15032014, 2014.

Tukey, J.: An introduction to the calculations of numerical spectrum analysis, in: Spectral Analysis of Time Series, edited by Harris, B., 25-46, Wiley, New York, USA, 1968.

van der Velde, Y., de Rooij, G. H., Rozemeijer, J. C., van Geer, F. C., and Broers, H. P.: Nitrate response of a lowland catchment: On the relation between stream concentration and travel time distribution dynamics, Water Resour. Res., 46, W11534, doi:10.1029/2010WR009105, 2010.

van der Velde, Y., Heidbüchel, I., Lyon, S. W., Nyberg, L., Rodhe, A., Bishop, K., and Troch, P. A.: Consequences of mixing assumptions for time-variable travel time distributions, Hydrol. Process., 29, 3460-3474, doi:10.1002/hyp.10372, 2015.

Vogel, J. C.: Investigation of groundwater flow with radiocarbon, in: Isotopes in hydrology, 355-369, International Atomic Energy Agency, Vienna (Austria), 1967.

Weissmann, G. S., Zhang, Y., LaBolle, E. M., and Fogg, G. E.: Dispersion of groundwater age in an alluvial aquifer system, Water Resour. Res., 38, 1198, doi:10.1029/2001WR000907, 2002.

Zuber, A., Witczak, S., Rozanski, K., Sliwka, I., Opoka, M., Mochalski, P., Kuc, T., Karlikowska, J., Kania, J., JackowiczKorczynski, M., and Dulinski, M.: Groundwater dating with ${ }^{3} \mathrm{H}$ and $\mathrm{SF}_{6}$ in relation to mixing patterns, transport modelling and hydrochemistry, Hydrol. Process., 19, 2247-2275, doi:10.1002/hyp.5669, 2005. 